\title{
Clínica Psicanalítica: Aproximações Histórico-Conceituais e Contemporâneas e Perspectivas Futuras
}

\author{
Luiz Augusto M. Celes ${ }^{1}$ \\ Universidade de Brasília
}

\begin{abstract}
RESUMO - O texto propõe uma revisão crítica da psicanálise, enfatizando sua origem em Freud e suas conquistas mais recentes. Marca a evolução da obra freudiana pelos seus principais balizamentos, a saber, a descoberta, a importância e o alcance do inconsciente e as questões da intensidade, sexualidade, pulsionalidade e das relações de objetos, suas variações, avanços e retrocessos. Identificam-se três modelos que guiam o pensamento psicanalítico originário e suas derivações: o neurótico, o melancólico e o paranóico. $\mathrm{O}$ texto sugere ainda demarcar os principais aspectos em evidência na psicanálise atual, incluindo autores brasileiros. Finalmente, dedica-se a uma reflexão sobre os vetores que poderão guiar o futuro da psicanálise em termos de seus aspectos teóricos e clínicos, sua área de atuação e suas relações com a cultura.
\end{abstract}

Palavras-chave: psicanálise; inconsciente; sexualidade; pulsão; relações de objeto.

\section{Psychoanalytic Practice: \\ Historical, Conceptual and Contemporary Approaches and Future Perspectives}

\begin{abstract}
This essay proposes a critical review of psychoanalysis, emphasizing its origin in Freud and its more recent achievements. It points out the evolution of Freud's work by means of its most important markers, namely, the discovery, importance and scope of the unconscious, and issues concerning intensity, sexuality, pulsion (trieb) and variations, advances and retreats of object relations. Three guiding models of the original psychoanalytic thought and its derivations are identified: the neurotic, the melancholic and the paranoid. The main aspects in evidence in contemporary psychoanalysis are also emphasized, including Brazilian authors. Finally, it is presented a reflection on the vectors that may guide the future of psychoanalysis with respect to its theoretical and clinical aspects, areas of expertise and relations with culture.
\end{abstract}

Keywords: psychoanalysis; unconscious; sexuality; pulsion; object relations.

O convite para participar deste número especial de Psicologia: Teoria e Pesquisa, em comemoração dos seus 25 anos de existência, é para nós uma honra e traz-nos a oportunidade de recuperar uma visão geral da psicanálise, relembrar sua fundação e delinear algumas de suas principais matrizes na atualidade até propor vetores de desenvolvimento para seu futuro. Dada a natureza da demanda a este texto dirigida, ele não poderá conter detalhes de considerações técnicas muito precisas, embora pretenda ser rigoroso e fidedigno. $\mathrm{O}$ que apresentamos a seguir será uma tomada em perspectiva dos aspectos históricos e contemporâneos da psicanálise, seguida de uma visada no sentido de sugerir algum cenário para o seu futuro. As duas primeiras considerações estarão sob a dependência de nossa interpretação, pois sabe-se que a psicanálise caracteriza-se por uma multiplicidade de abordagens que não se sintetiza facilmente (talvez jamais), o que impõe necessários recortes para uma abordagem geral e em perspectiva. Portanto, interpretação e recortes determinam o desenvolvimento deste texto. Ainda sobre as duas primeiras tomadas do texto, não se fará um apanhado histórico objetivo, melhor dizendo, não se fará e não se pretende fazer aqui uma história da psicanálise. Não somos historiadores nem das ci-

1 Endereço para correspondência: Departamento de Psicologia Clínica, Instituto de Psicologia, Universidade de Brasília, Campus Darcy Ribeiro. Brasília, DF. CEP 70910-900.E-mail: celes@unb.br. ências, sequer da psicanálise. Mas temos, os psicanalistas, o hábito de recorrermos às origens de nossa disciplina e prática, porque nos são inspiradoras. A psicanálise passou por grandes mudanças, cujos motivos são diversos e apoiam-se nos seus próprios avanços internos, determinados pelos limites de sua técnica, de seu método, e pelas exigências advindas do mundo onde se desenvolveu e desenvolve, com vistas à sua adaptação e atendimento às demandas que lhe chegam. Apesar das profundas mudanças, as origens da psicanálise marcam a índole de sua teoria e clínica, uma vez que suas descobertas fundamentais lá se encontram, quais sejam, adiantando, a descoberta e conhecimento do inconsciente e da sexualidade como os fatores em torno dos quais se organizam as subjetividades. Teoria do inconsciente e teoria pulsional, clínica do inconsciente, segundo o processo da interpretação, e clínica da pulsão, segundo a atenção dada à economia psíquica, são os marcos fundamentais da psicanálise e apoio de todo seu desenvolvimento (e, por que não dizer, de seu progresso). Mesmo alterações que explicitamente não se afinaram ao desenvolvimento freudiano - afastando-se das concepções do inconsciente sistemático e da pulsão como o propulsor das estruturações psíquicas nos humanos - partiram de Freud e em face crítica com ele se desenvolveram. Até as concepções psicanalíticas que mais se distanciam das freudianas, como a das relações de objetos (e.g., Fairbairn, 1952/1999), mantêm com elas referências críticas. Assim, 
iniciaremos nossas discussões estabelecendo o sentido freudiano da psicanálise, estender-nos-emos em concepções após Freud, sejam freudianas ou não, buscando rapidamente caracterizá-las, esclarecer suas motivações e delimitar seus pontos de inflexão.

Por fim, vamos sugerir alguns cenários para o futuro da psicanálise. Nesse aspecto, não há feito para se olhar, mas sugestões a partir de avaliações do que correntemente se dá. Com isso, não estaremos sujeitos ao erro de interpretações ou à sua demasiada parcialidade. A questão será a de uma esperança que seja vã e que somente o futuro avaliará. Estamos assim munidos de nossas desculpas e de alguma introdução temática já realizada, da qual se pode averiguar sua índole.

Ainda uma ressalva. $\mathrm{O}$ convite por nós recebido para este artigo tinha como título do campo a ser abordado "Clínica psicanalítica”. Buscaremos ser fieis à sugestão contida nesse título. Isto não é muito difícil de ser atendido. Embora se possa tomar a psicanálise como pura teoria, como pensamento ou filosofia (Figueiredo, 2000), sua inspiração e origem não é essa. É clínica. A psicanálise é o nome do trabalho de tratamento das neuroses. "Psicanálise" é o nome de batismo desse trabalho, é o nome próprio de uma prática de tratamento que teria alcançado desenvolvimentos inicialmente inimagináveis, já constatava seu fundador (Freud, 1925/1989d). A partir de uma prática de tratamento, desenvolveu-se até alcançar uma compreensão total dos homens e de seus destinos, tornando-se de importância para a ciência e para a vida. Maior alcance se pode verificar na psicanálise hoje, comparada com o que Freud propôs, embora certo otimismo revolucionário da psicanálise se tenha arrefecido um tanto em seus 110 anos de história. Mas as artérias onde circulam o sangue renovado e renovador da psicanálise foram e permanecem sendo clínicos. Em sua prática, a psicanálise esbarrou-se com as críticas que motivaram o seu desenvolvimento, suas mudanças, transformações e reviravoltas. Desse modo, a teoria psicanalítica encontra seu sentido na clínica, seu lugar de experiência e seu crivo, sem que possamos afirmar, ilesos, tratar-se a clínica da aplicação da teoria. Embora esta se torne parcialmente autônoma, a ponto de se poder fazer da psicanálise uma filosofia (ou nela se inspirar para isso), o vetor de construção da teoria psicanalítica é no geral inverso: do trabalho de psicanálise à teoria. Assim, não fazemos distinção rígida entre a teoria e a prática. Assumimos a formulação de que a teoria em psicanálise é teoria da clínica psicanalítica, é teoria de sua prática, embora nem sempre seja teoria de sua técnica. Mas a teoria é a formulação da compreensão clínica, mesmo em seus momentos mais abstratos, mais metapsicológicos.

\section{Principais Balizas da Clínica Psicanalítica}

\section{Todos somos "neuróticos" e todos somos "perversos"}

O título francamente provocativo deste subitem necessita ser matizado e carrega toda a índole revolucionária da psicanálise de que falamos acima. De fato, a psicanálise surge como negatividade, se confrontada com a longa tradição do pensamento ocidental que, desde o seu nascimento na Grécia antiga, se apoia no logos e em sua força (Vaz, 1974). Não há avaliação que não reconheça no logos filosófico e depois científico toda a potência do desenvolvimento ocidental (para o bem ou para o mal, pode-se acrescentar). A hegemonia do Ocidente nele se apoia; e o Oriente que ensaia sua hegemonia, submeteu-se ao logos científico e tecnológico e dele faz uso pleno. É verdade que assim não aconteceu simplesmente pela força do pensamento científico. A ele precisa-se acrescentar o modo de produção capitalista do qual se conhecem os benefícios e as perdas para nossas vidas. Enfim, não é esse o nosso tema, mas o é a psicanálise e seu aspecto negativo com respeito, grosso modo, ao que se vinha desenvolvendo no pensamento ocidental hegemônico ${ }^{2}$. A negatividade que a psicanálise representa para o pensamento Ocidental, que a funda e se constitui vetor de seu desenvolvimento e de sua riqueza e originalidade se expressa na teoria do inconsciente e na teoria da sexualidade. Pois, então, tomado o inconsciente como a base da neurose e esta, no sentido amplo e geral, como o que se caracteriza pelo inconsciente, a obra angular que é a Interpretação dos sonhos (Freud, 1900/1987a) justamente permite ampliar a presença do inconsciente em toda ação humana. $\mathrm{O}$ inconsciente passa a ser o psíquico como tal, em oposição ao psíquico como consciência e razão, que caracteriza a compreensão e a base do pensamento Ocidental. Se todos somos inconscientes, no sentido sistemático, se a maior parte de nossa vida mental se passa inconscientemente e no inconsciente, todos somos "neuróticos". Se nossas ações são derivadas do recalcado, todos somos, de modo geral, neuróticos, e elas, as ações, são, em alguma medida, sintomáticas, o que justifica a consideração da psicopatologia presente na vida cotidiana (Freud, 1901/1989h). A natureza inconsciente do psiquismo é um dos fatores que trouxeram para a psicanálise o seu sentido revolucionário, no que diz respeito ao tratamento da neurose, à compreensão do humano e da base do pensamento.

\section{Inconsciente e interpretação}

À descoberta e afirmação do psiquismo inconsciente se associa a clínica psicanalítica da interpretação. A interpretação se constitui no método de acesso ao inconsciente recalcado, meio pelo qual o neurótico se desembaraça do sintoma. Tendo Freud muito cedo se desvencilhado do objetivo de superação dos sintomas dos neuróticos, rapidamente, já em 1905, estabelece que a cura dos sintomas constitui-se um ganho secundário do tratamento psicanalítico (Freud, $1905 / 1989$ c). Significa com isso uma mudança profunda no método que Freud desenvolvia no fim do séc. XIX, qual seja, o método catártico, associado à análise da memória recalcada, método este que havia sido estabelecido por Breuer (cf. Freud \& Breuer, 1895/1987) e fartamente utilizado por Freud. Não mais se trata a neurose, mas o próprio sujeito que não se deslindará do inconsciente. Sobre o inconsciente se busca um conhecimento profundo, para que o indivíduo possa apoderar-se de si, ainda que não de modo absoluto, de suas

2 São considerados pensadores da negação, Nietzsche, Marx e Freud. Conjunção singular, embora não se encontrem entre eles influências mútuas viscerais. 
decisões, e assumir para si a responsabilidade de seus desejos (por seu inconsciente, embora dele, ele escape). Inicia-se um movimento de "etificação" (e.g., França, 1996; Katz, 1984; Kehl, 2002; Szasz, 1983), por assim dizer, da psicanálise e sua aproximação à antropologia, sendo a ética de que se trata a do desejo. Mais que isso, estabeleceu-se, com a interpretação como método da psicanálise, uma confiança com respeito à linguagem na qual Lacan teria se apoiado (Kristeva, 1996) para recuperar a psicanálise segundo seus eixos originários, que teria se perdido após Freud.

Embora esteja no próprio fundamento do psiquismo inconsciente a ideia da impossibilidade de dissolução do inconsciente, o tratamento tem como horizonte teórico tal alcance, mas um horizonte, ao qual, como acontece com o horizonte efetivo, não se chega. A mudança técnica ocorrida foi profundamente coerente com o entendimento que se alcançou na Interpretação dos sonhos (Freud, 1900/1987a), que estabeleceu a não exclusividade neurótica do inconsciente. Somos todos inconscientes em nossos desejos mais profundos e significativos, somente uma parte de nossos pensamentos é consciente e deles pouco temos conhecimento; portanto, somos todos neuróticos no sentido mais geral do termo. $\mathrm{O}$ modelo do sonho, que não se especializa somente na proposta lacaniana, adquire, como o sugere Green (2003a), todo seu vigor para o tratamento psicanalítico e, embora secundado por determinado período, retoma contemporaneamente seu lugar privilegiado na clínica psicanalítica e na compreensão da constituição e estruturação do psiquismo, certamente com a influência determinante da releitura de Freud proposta por Lacan.

\section{A intensidade (primeiras aproximações)}

Entretanto, nem somente de significado (de linguagem) vivem os homens, embora seja essa uma das descobertas fundamentais da psicanálise freudiana. A vivacidade do discurso ou da narrativa que propicia interpretação e realiza interpretação nunca esteve fora da atenção de Freud, e nem se instalou na preocupação psicanalítica de modo secundário. A intensidade da experiência e a intensidade da ideia recalcada ou reprimida sempre estiveram na mira das considerações freudianas, como elemento de recalque e como fator de tratamento. Desde a primeira formulação do método do tratamento psicanalítico (Freud \& Breuer, 1895/1987), a expressão do afeto que acompanha a lembrança recalcada torna-se a exigência e a condição para a dissolução do sintoma neurótico, é o método de cura, como então se o entendia. Como elemento de recalque, será a ideia insuportavelmente intensa o alvo do recalque, e sua intensidade deslocada determinará o sintoma histérico, como se observa na mesma obra de Freud e Breuer. Rapidamente se apresenta, na clínica freudiana, a descoberta da origem da insuportável intensidade afetiva, qual seja, a experiência sexual prematura, impossível de ser elaborada ou significada. Prematuridade que resistiu à compreensão circunstancial e mostrou-se ser a regra da experiência sexual, como veremos a seguir.

Elabora-se, no período de 1895 a 1905, o que se constitui o segundo pilar do edifício psicanalítico, qual seja, a teoria da sexualidade. Essa teoria, apresentada em Três ensaios sobre a teoria da sexualidade (Freud, 1905/1989j), constitui-se, inicialmente, como ensaios, como uma abordagem hesitante de Freud sobre a força determinante mais radical do desenvolvimento psíquico. A partir desse livro, a sexualidade é elevada ao conceito, e assim permanece, de sexualidade infantil. Esta não designa simplesmente a sexualidade presente na infância, nem a sexualidade presente na experiência sexual infantil. "Sexualidade infantil" deve ser tratada como o conceito de sexualidade na psicanálise. Ela designa um modo de sexualidade que está presente na infância, mas se prolonga, jamais sendo superada, por toda a vida do sujeito. A sexualidade infantil é aquela que de maneira mais evidente se manifesta no adulto perverso, e que no neurótico ou no normal-neurótico permanece ativa em suas fantasias: mostra-se distorcida nos sintomas neuróticos e mantém-se sob forte recalque no normal-neurótico. A sexualidade infantil, mais precisamente, os representantes das experiências sexuais infantis são os alvos do processo de recalcamento. A sexualidade é compreendida, desde então, como prematura por natureza (ver Celes, 1994). A sexualidade infantil, perversa-polimorfa, constitui-se a sexualidade por excelência, sendo considerada a sexualidade originária. A sexualidade dita adulta e genital é resultado de uma transformação da sexualidade originária, e dela conserva seus traços. De tal maneira que jamais o sujeito se liberta completamente da influência das primeiras experiências sexuais, mesmo que essas vigorem de modo modificado, sob a determinação dos diversos deslocamentos e condensações característicos das representações recalcadas.

Somos todos "perversos" no sentido geral, pois a sexualidade humana é polimorfa em sua origem e vigência, sendo seus delineamentos adquiridos ao longo do desenvolvimento afetivo sexual. No entanto, não há no entendimento psicanalítico inaugural uma concepção desenvolvimentista da sexualidade. O desenvolvimento de que se trata é, segundo uma metáfora utilizada por Freud, como as larvas de um vulcão: cada camada permanecendo intacta sob as camadas que se constituem de erupções posteriores. Uma prospecção geotécnica as identificaria todas, como acontece com a prospecção psíquica proporcionada pelo trabalho de psicanálise. As representações das experiências sexuais infantis presentificam-se no trabalho de análise. Nessa perspectiva se fia o tratamento psicanalítico que, se não consegue liquidar o inconsciente, tampouco desfará de maneira completa as marcas e as repetições das experiências sexuais infantis, permanecendo estas mais ou menos integradas ao comportamento dos sujeitos. Certa disponibilidade do próprio desejo (que sempre será infantil ou terá suas raízes na sexualidade infantil) talvez seja o máximo que se pode esperar do tratamento psicanalítico.

Pontalis (1997) sugere que o que há de mais caracteristicamente originário na psicanálise é precisamente a ideia de que o tempo não passa. Lá, por assim dizer, no fundo do nosso inconsciente, permanecemos infantis como o fomos (Tanis, 1995; Zavaroni, Viana \& Celes, 2007), permanecemos impulsionados pelas marcas indeléveis das experiências de satisfação que então gozamos. Na psicanálise freudiana do modelo neurótico não há entendimento de que o "desenvolvimento" psíquico se compromete por carência, mas por excesso. A experiência de prazer muitas vezes repetidas, vi- 
ciada, como o dirá Freud no caso Dora (Freud, 1905/1989c), fixa-se, atraindo para si impulsos posteriores de satisfação.

No entanto, nem todo sintoma, nem todo sonho, nem todo ato falho pode ser interpretado, dele não se pode achar o seu núcleo recalcado. Freud já havia indicado em 1895 (Freud \& Breuer, 1895/1987) que nem todo sintoma histérico se deixa interpretar completamente. Na Interpretação dos sonhos (Freud, 1900/1987a), o umbigo do sonho ocupa o lugar do impossível de ser deslindado; as cenas mais primitivas somente poderão ser construídas pelo analista (Freud, 1937/1986a), indicando-se, assim, o limite da interpretação como simples doação de sentido, mesmo que dela ativamente participe o analisando no trabalho que lhe cabe de associação livre. $\mathrm{O}$ limite da análise e o limite do compreensível no humano anunciam-se em Freud como fantasias originárias, que seriam algumas limitadas matrizes filogeneticamente adquiridas que guiariam a constituição e a estruturação do psiquismo. As inelutáveis fantasias originárias da cena primitiva, da sedução e da castração seriam organizadores herdados — herdados pela linguagem, sugere Forrester (1980) — da vida pulsional primitiva nos seres humanos: núcleos do inconsciente.

\section{Pulsão sexual e pulsão de autopreservação}

À organização do inconsciente, além do recalcado propriamente dito - constituído pelo recalque originário, pelas fantasias originárias - , associam-se as elaborações sobre a força que impulsiona o sujeito em oposição ao otimismo inicial da psicanálise. Inicialmente restrita à sexualidade como experiência vivida, que, portanto, poderia adequadamente oferecer-se à interpretação, a compreensão da psicanálise estendeu-se ao limite entre o psíquico e o orgânico com a noção de pulsão. A sexualidade infantil rapidamente se caracterizou em Freud como pulsional, como força incessante de origem somática que se apresenta como exigência de trabalho psíquico. O entendimento radical do psiquismo em conflito se constituiu inicialmente na oposição entre a pulsão sexual e a pulsão de autopreservação. Forças pulsionais sexuais, regidas pelo princípio do prazer, contra forças egoicas, também pulsionais, regidas pelo princípio de realidade, constituem a primeira formulação do conflito psíquico na psicanálise. As pulsões de autopreservação têm sentido além das de forças internas que visam a manutenção e conservação da vida do organismo. Elas são marcadas pelas exigências culturais, formatadas e modeladas pela educação, pela consciência moral e pela vida civilizada. As pulsões de autopreservação condensam tais aspectos ou pouco os discriminam. $\mathrm{O}$ eu é suposto, nas formulações sob o império do modelo neurótico, um dado inquestionável, natural quase.

O modelo neurótico da compreensão do psiquismo e da clínica baseada na interpretação, segundo o enquadre guiado pela regra fundamental da associação livre, caracteriza o que se convencionou chamar "psicanálise padrão". Convém lembrar que designamos tal compreensão freudiana de "modelo neurótico" baseados numa extensão, que talvez não seja totalmente apropriada, do conceito freudiano de neurose. Green (2003a, 2003/2005) sugere dizer "modelo do sonho", em referência explícita à Interpretação dos sonhos, em contraposição ao modelo mãe-bebê, que a frente retomaremos. O enquadre clínico em questão, lembremos, é o que parcialmente se expressa no senso comum com respeito à psicanálise: o divã, onde o analisando se reclina, adotando a atitude a mais livre possível diante dos seus próprios pensamentos, que se requer que os diga em voz alta. Fora de sua vista, posiciona-se o analista em atitude de atenção livremente flutuante, que é a atitude correspondente à associação livre do analisando. A atenção do analista se completa com a neutralidade benevolente que lhe permita permanecer na posição simultaneamente engajada e distante (em reserva) com respeito ao analisando e seu discurso. A regra da associação livre designa a atitude fundamental do analisando em análise. Ela não corresponde diretamente à exigência de um discurso em associação livre. Como bem o lembra Green (1983/1988), o discurso do analisando é sempre de início um discurso narrativo; somente a escuta do analista, sua devida atenção flutuante, trará a esse discurso o seu caráter associativo (Celes, 2005a). Jamais fez parte do pensamento psicanalítico considerar o analisando como uma espécie de máquina associativa, independente do analista, o qual, por seu turno, estaria na posição de neutralidade e frieza absolutas. Essa ideia corresponde a outro senso comum com respeito à psicanálise que não se cumpre; é lícito se afirmar que tal ideia muito se faz presente no afã curativo e otimista de psicanalistas iniciantes, que não teriam se submetido, eles mesmos, a uma profunda análise pessoal. Percebe-se, desde então, para completarmos esse pensamento sobre a clínica psicanalítica, por quais rigorosos caminhos, composto de análise pessoal, estudos e supervisão, deve passar a formação do psicanalista.

\section{O pulsional e o narcisismo (o eu e o objeto)}

O modelo do conflito neurótico de que viemos falando encontra sua crítica na reflexão sobre as psicoses, iniciada com o caso Schreber (Freud, 1911/1987b). Tal crítica se estenderá na consideração sobre o narcisismo, estado inicial responsável pela constituição e pelo desenvolvimento do eu. Sendo, então, o eu resultado do investimento libidinal do corpo próprio, não haveria mais sentido pensar-se na pulsão egoica de autopreservação que fosse independente da sexualidade. A pulsão de eu se entende, então, como a libido retida no eu, sendo o conflito pulsional estabelecido entre a pulsão de eu e a pulsão de objeto, ou seja, a libido que a partir do eu é dirigida ao objeto. Trata-se agora de conflito da distribuição de libido, e regido pela forte oposição entre o amor-próprio e o amor de objeto. O narcisismo se constitui fase intermediária entre o autoerotismo (estado inicial da sexualidade presente desde o modelo neurótico do psiquismo) e o investimento de objeto. O narcisismo, assim, constitui-se como uma interposição, na perspectiva do desenvolvimento do psiquismo, que se consolida com a formação do eu como instância psíquica. $\mathrm{O}$ eu, então, se torna estruturalmente mediador entre o isso (fonte e origem das pulsões) e o mundo externo.

No entanto, o mundo externo não será jamais líquido e certo, o que se encontra fora do psiquismo, pois muito do mundo com que o eu se vê confrontado, se não todo, se constitui de objetos internalizados. Sejam estes os objetos da identificação, com os quais o eu se compõe de modo mais 
ou menos integrado, sejam os objetos da identificação que se destacam do eu, constituindo os ideais, segundo Freud (1923/1989b), e, mais precisamente, o superego, sejam, ainda, numa perspectiva após Freud, objetos incorporados (Abraham \& Törok, 1987) que assim têm vigência no interior do psiquismo, mas como corpos estranhos ao eu. Os "objeto excitante" e "objeto rejeitante", em relação estreita com partes do ego como "ego libidinal" e "sabotador interno", respectivamente, como os distinguirá Fairbairn (1952/1999, p. 105), e os objetos concretos no interior do psiquismo (Bion, 1967/1994) bem ilustram a independência dos objetos incorporados e sua ação de cisão sobre o ego.

Se usamos a neurose como base do modelo freudiano da sexualidade, a economia da distribuição libidinal entre o eu e o objeto encontra seu apoio na melancolia, porque nela se condensam os destinos da economia pulsional aliados aos investimentos de objetos com os quais o eu se identifica, no mesmo passo em que neles se aliena, num conflito de integração e cisão do eu, por meio dos processos de identificação e incorporação. Por homogeneidade e paralelismo à elaboração que viemos desenvolvendo, sugerimos nomear aqui "modelo melancólico" o entendimento freudiano do conflito que agora se põe em evidência.

Em um dos muitos aspectos do pensamento de Green, o modelo melancólico é explorado e conduzido adiante. A partir de uma retomada crítica do pensamento freudiano, Green (1983/1988) busca discriminar modos do narcisismo que possam dar sustentação à compreensão de formas psicopatológicas contemporâneas. O tema da "mãe morta" (Green, 1983/1988) e da constituição dos limites psíquicos ganha relevo e é retomado por diversos psicanalistas contemporâneos (Kohon, 1999). Entretanto, as psicopatologias contemporâneas muito são utilizadas, por diversos autores e correntes em psicanálise, para fundamentar compreensões psicanalíticas distintas das freudianas, como o abandono da preponderância do pulsional na constituição subjetiva, e para colocar em segundo plano o Édipo como núcleo da organização subjetiva. Alguns autores utilizam-se da reflexão greeniana voltada para a consideração da psicanálise em suas diversas facetas, para justificar seus afastamentos ou suas aproximações de Freud. Green parece-nos mais rigoroso e cuidadoso, pois inspirado em Freud, Winnicott e outras teorias do psiquismo, como a de Bion, busca uma reflexão do conjunto da psicanálise, sem a preocupação de fazer uma grande síntese, ademais inexecutável, objetivando aproximações críticas entre suas partes, a fim de pensar, sem abandonar a teoria pulsional nem a das relações de objeto, uma metapsicologia que sustente ou faça jus às novas demanda de psicanálise, notadamente as advindas dos nomeados estados narcisistas, borderlines, casos limites, enfim, estados psíquicos nos quais estariam em questão a constituição do psiquismo, ele mesmo, e sua delimitação.

No entanto, os movimentos da psicanálise em direção ao que se convencionou chamar de teoria das relações de objeto é anterior às reflexões de Green e mantêm-se independentemente desse autor, embora por vezes se busque nele alguns apoios. A teoria das relações de objeto, plural que seja, segundo um de seus mais expressivos adeptos na atualidade (Ogden, 2002/2003), sustenta de modo geral a compreensão de que estados muito primitivos da constituição do psiquismo são os responsáveis por diferentes estruturas psíquicas não neuróticas: casos limites, narcisistas, borderlines e psicóticos, mas também estados depressivos como os caracteristicamente contemporâneos. É verdade que não se pode fazer tábula rasa dessas diversas configurações psíquicas, pois tais configurações mantêm características específicas e não encontram na psicanálise abordagens propriamente uniformes. No entanto, não aprofundaremos tais desenvolvimentos, pois o foco de nosso interesse neste momento não se refere aos quadros assim descritos ou classificados.

Mais nos interessa é caracterizar de modo geral a teoria das relações de objeto, o multifacetado movimento psicanalítico assim conhecido. Podemos completar que sustentam a ideia de que questões dos limites do psiquismo e da sua constituição se evidenciam nas condições primitivas do desenvolvimento. E que esses limites, sua formação ou má formação, estão na dependência direta das relações primitivas com objetos primitivos (portanto, objetos não inteiros), relações estas responsáveis pela constituição do si-mesmo (self). Os limites entre o self e o não-self, entre o eu e o nãoeu, entre o psíquico e o não-psíquico, entre o dentro e o fora, a experiência de discriminação com o objeto - contrária à experiência da presença concreta dos objetos no interior do psiquismo de que falamos — seriam os responsáveis pela boa diferenciação e constituição do self. Tais limites estariam na dependência direta da qualidade das relações com os objetos primitivos. Essas considerações são diferentes da concepção freudiana que credita à pulsionalidade natural e característica dos humanos os destinos do psiquismo, de sua estruturação, como defesas contra a pulsionalidade "selvagem", originária e incontrolável. Para os teóricos da relações de objeto, o atendimento às necessidades básicas do bebê para o seu desenvolvimento é que determina o destino da subjetivação (desde a constituição de uma subjetividade diferenciada, uma personalidade harmoniosa, não cindida, até o limite da inexistência do subjetivo como tal). W. Ronald D. Fairbairn (1889-1964), certamente pioneiro da teoria das relações de objeto (Fairbairn, 1952/1999) ${ }^{3}$, sugerirá entender a constituição psíquica básica como esquizoide, sendo a esquizoidia seu parâmetro de pensamento, numa referência explícita à impossibilidade de integração efetiva do ego (no caso, entendido como a personalidade total), pelo simples motivo de que nenhum objeto, por mais dedicado que seja, poderá atender sem falhas e sem hesitações as necessidades fundamentais do início da vida humana. Em Fairbairn se inspiram as reflexões sobre as relações primitivas de objetos (Grotstein, 2000).

Encontram-se ecos do pensamento de Fairbairn em Winnicott, embora não citados. Tendo em vista a forte influência de Donald W. Winnicott (1896-1971) nas cogitações sobre as relações de objeto, e considerando sua atualidade inquestionável, inclusive no Brasil ${ }^{4}$, a observação da especificidade de seu pensamento torna-se importante para marcar o desenvolvimento da clínica psicanalítica. A obra winnicottiana tem

3 Veja também: Celes (2006); Celes, Alves e Santos, (2008); Celes, Santos e Alves, (2006); Figueiredo (2000), dentre outros.

4 Veja, por exemplo, as contribuições das obras de Bezerra Jr. e Ortega (2007); Outeiral, Hisada e Gabríades (2001); Outeiral, Hisada, Gabríades e Ferreira (2005), dentre muitas outras. 
sido bastante explorada e não tem sentido tentar sua exposição neste espaço com qualquer ambição de abrangência ou mínimo de completude. Interessa-nos observar que distante da consideração singular dos objetos primitivos, Winnicott (e. g. 1975/1978, 1979/1983) apreende o seu caráter como de ambiente: nos momentos primitivos da existência, os objetos não são objetos, mas ambiente em relação ao qual o bebê se encontra indiferenciado. O desenvolvimento se dá, para o autor, como processo de diferenciação de ambos, do bebê como self e do ambiente como objeto (ou como constituído de objetos). O duplo movimento, de diferenciação do si-mesmo em relação ao ambiente e de diferenciação do ambiente como objetos, enseja praticamente todo o pensamento de Winnicott, que o concebe complexo e paradoxal, no qual se constitui o espaço potencial e transicional entre o bebê e o ambiente. No espaço potencial, o objeto é criado e dado: o objeto que o bebê cria, ele o encontra dado pela mãe-ambiente. A adequação da mãe-ambiente ("mãe suficientemente boa") na apresentação dos objetos da necessidade do bebê, justo no momento da emergência da necessidade, será para Winnicott (1975/1978) a condição para a constituição do verdadeiro self, que se distingue do falso self, este que será uma organização defensiva das invasões indevidas do meio: sua antecipação, sua inadequação para atender à necessidade etc. ${ }^{5}$ Nessa medida, o pensamento de Winnicott também se afasta da teoria pulsional e da responsabilização do Édipo como constitutivo e estruturante da subjetividade, respectivamente.

A clínica winnicottiana e a que é nela inspirada têm por perspectiva a reconstituição do self, para o que o ambiente da análise se faz de importância evidente. $\mathrm{O}$ ambiente da análise, no qual se inclui o analista, é assim considerado pela diferença com a importância capital que ganha o analista como objeto, seja do investimento libidinal (para os freudianos), seja como anteparo das identificações projetivas (para os psicanalistas de inspiração nas relações de objeto, numa vasta gama de concepções, dos kleinianos aos bionianos). $\mathrm{O}$ ambiente de análise dos winnicottianos tem o propósito de "reproduzir" o ambiente primitivo materno. Nesse sentido, a técnica da análise se transforma para uma psicanálise modificada, em que a regressão efetiva do analisando (não somente a regressão tópica, temporal e formal aos processos mais primitivos do funcionamento psíquico inconsciente), a sua regressão ao estado de dependência absoluta (ou quase isso), se alia aos procedimentos de holding propiciados pelo analista e o ambiente, para definir o enquadre de análise. $\mathrm{O}$ holding de que se fala raramente é físico, como o observa Winnicott (1979/1983), e nesse contexto a interpretação é entendida como forma de acolhimento e compreensão (e não propriamente uma intervenção para dar sentido). Tal situação de análise é chamada de modificada em relação à considerada psicanálise padrão, de inspiração freudiana, que se baseia na livre associação e na atenção livremente flutuante, entre analisando e analista, respectivamente, como acima expusemos.

Afastamo-nos deliberadamente de Freud e chegamos a posições psicanalíticas que não estão conforme sua obra e

5 Algumas outras significativas coleções: Winnicott (1971/1975, 1988/1990, 1986/1996); Winnicott, Shepherd e David (1989/1994). seus princípios. No entanto, ensejados pela questão do narcisismo e das relações com os objetos, pudemos introduzir o que se elaborou após Freud com respeito ao tema. É certo que o narcisismo foi abandonado como estrutura fundamental e fundante dos processos de subjetivação. O tema do self ou da personalidade desenvolvido pelos psicanalistas das teorias das relações de objeto permanece alheio ao conceito de narcisismo. O narcisismo supõe, de fato, tal como Freud o pensou, um investimento inicial da libido no corpo próprio que os teóricos das relações de objeto, grosso modo, somente conseguem entender como partindo do objeto. Essa discussão é muito longa e prenhe de filigranas que não podem aqui ser desenvolvidos. No entanto, Green (1983/1988) teria, desde o início de sua obra, não obstante sua aproximação de Winnicott e Bion, sugerido a retomada do narcisismo como conceito fundamental, reaproximando-se do que acima chamamos de modelo melancólico. Para a articulação do narcisismo com a melancolia, o autor busca integrar a pulsão de morte.

\section{Terceiro movimento pulsional: Eros e pulsão de morte}

Embora a concepção do narcisismo tenha um lastro clínico - a partir das experiências de análise, sejam elas fragmentadas nos neuróticos, sejam com base na literatura, como no caso Schreber (Freud, 1911/1987b), sejam nas observações e compreensões de Freud sobre a situação dos homens em seus ambientes culturais (e. g. Freud, 1921/1989g) -, a postulação do monismo pulsional que decorre do narcisismo e o entendimento do conflito transportado para as relações entre o eu e o objeto parecem não se adequar completamente à experiência freudiana em sua extensão. No entanto, não será pelo caminho das relações de objeto, tal como posteriormente se desenvolveram, que Freud seguiu. Quer dizer, toda a obra posterior de Freud testemunha que sua concepção não se desenvolveu tendo por suposto a importância quase exclusiva ou principal das relações de objeto sobre a estruturação do psiquismo. Com isso, não devemos entender uma oposição de Freud às considerações quanto ao eu e ao objeto, ele as mantém, mas segundo uma base de entendimento pulsional.

De fato, o eu tomado como questão a ser desenvolvida pela psicanálise rendeu muitos avanços às considerações freudianas, além das já indicadas para o entendimento da melancolia e das psicoses de modo geral. A partir daí, Freud (1923/1989b) alcançou formular o que se conhece por segunda tópica, uma concepção estrutural do psiquismo, denominação dada pela psicanálise anglo-saxônia à proposta da constituição psíquica em três instâncias: isso, eu e supereu (id, ego e superego, caso se siga a tradição da tradução inglesa). A segunda tópica: (a) introduz a relação do psiquismo com o mundo externo, estando além da proposta da primeira tópica, cujo contato do psiquismo com o mundo se daria, por hipótese, somente pela percepção, percepção esta que não é distinguível da percepção das excitações advindas do interior do próprio corpo, pois não haveria critério que as diferenciasse; (b) considera dois modos distintos e qualificados de participação e presença do mundo externo no psiquismo, como o "eu" e o "supereu", diferentemente da consideração de que o mundo se presentifica no psiquismo somente como cargas de excitações advindas da percepção; 
(c) possibilita a efetiva compreensão das relações entre o sujeito e a cultura (ou civilização), como relações internas ao processo de subjetivação, entranhadas na própria constituição e definição do psiquismo, e não, consideradas somente com base em relações externas; (d) possibilita pensar os aspectos da cisão do próprio eu no psiquismo, e não somente a separação do psiquismo entre o consciente, pré-consciente e o inconsciente; e (e) compreende os processos defensivos que resultam na cisão egoica, portanto, além do recalque que separa o inconsciente do consciente, pré-consciente. Enfim, os avanços são sobremaneira significativos para a apreensão dos sujeitos não isolados, não considerados somente na perspectiva intrapsíquica, como se diz, mas do sujeito havendo-se com o mundo nos seus mais variados aspectos.

No entanto, tais avanços não parecem atender completamente à experiência freudiana, como já o dissemos, nem mesmo aos princípios nos quais a psicanálise se funda. A mais aparente desatenção acontece com o inconsciente sistemático que perde seu lugar como instância. Embora Freud $(1923 / 1989 b)$ tenha sugerido entender o inconsciente como parte do isso (Id), o recalcado e as representações inconscientes perdem, por assim dizer, seu lugar. Pode-se sugerir que o abandono desses aspectos não traria prejuízo para a clínica psicanalítica - uma vez que se a pensa a partir do modelo da melancolia; no entanto, o sentido das descobertas que sustentam a análise padrão permanecerá esmaecido. As experiências freudianas, por seu turno, continuam apontando para a importância da consideração do inconsciente sistemático no entendimento do que tange ao modelo neurótico: as neuroses propriamente ditas e as psicopatologias cotidianas, os desejos inconscientes, a sexualidade infantil e os "normais". Uma vez que, nos quadros neuróticos, também se identificam questões com respeito ao narcisismo e às relações com os objetos, isso sugere que não se deve abandonar nem o modelo neurótico nem o melancólico para a compreensão dos processos de subjetivação e para a clínica da psicanálise - um modelo de entendimento do psiquismo não exclui o outro. Parece-nos epistemologicamente sem sentido separar a psicanálise em duas. Entretanto, a importância das duas perspectivas não garante a viabilidade de uma integração ou síntese entre elas.

A psicanálise, nesse aspecto, mimetiza o que trata, parece reafirmar em sua teoria o princípio do inconsciente, aquele de que o tempo não passa. Os novos desenvolvimentos, na constituição psíquica e na psicanálise, mantêm um paralelismo de processos: o que uma vez aconteceu, não se perde, vigora, embora o faça de modo distinto que em sua origem. No desenvolvimento psíquico, o que uma vez se deu permanece fixado, associado a recalques posteriormente realizados, e se manifesta na forma de retornos do recalcado (sintomas, sonhos, atos falhos e o que mais for importante). No avanço da psicanálise, em sua evolução, antigas formulações e achados não perdem seu valor nem se integram de todo às novas formulações; vigoram parcialmente no que se avança e permanecem podendo ser considerados em sua independência. Os avanços da psicanálise não constituem sínteses teóricas e metodológicas que sejam completas e suficientes.

A experiência freudiana também aponta para questões que não se resolvem nem com o modelo neurótico nem com o melancólico. As experiências da compulsão à repetição, atualizada na análise da transferência e de experiências como a da reação terapêutica negativa, sugerem que Freud avance em outras considerações mais radicais que as da estruturação do psiquismo e de sua composição. Freud aí identifica um fator de princípio, justamente do princípio pulsional, além do psiquismo, de algum modo fora de seu alcance pleno e alheio, parcialmente, pelo menos, ao seu trabalho. Trata-se da pulsão de morte, considerada como o princípio pulsional por excelência, o mais pulsional da pulsão (Freud, 1920/1989e). À pulsão de morte foram agregados variados entendimentos: princípio segundo o qual todo organismo busca sua própria aniquilação; "desejo" de morte ou repouso absoluto do qual participa todo ser vivo; tendência própria à qualquer satisfação pulsional que busca o aniquilamento da excitação; tendência a zero; modo característico da libido desligada dos processos inconscientes; oposição ou tendência à destruição de todo vínculo, contrário à pulsão de vida (Eros) que busca a união cada vez mais abrangente do sujeito com os objetos e o mundo; agressividade e destrutividade como tal. Desde sua concepção como princípio o mais radical até a sua compreensão fenomênica como agressividade, a pulsão de morte é tomada em conflito originário com a pulsão de vida ou Eros. Eros une, a pulsão de morte visa desunir; Eros tende à vinculação cada vez mais abrangente entre os homens e seus mundos, a pulsão de morte visa destruir toda vinculação, toda formação comunitária, e tem por objetivo a simples destrutividade e o aniquilamento.

Afirma-se que Freud era pessimista e que sua concepção do homem e do humano assim o é. Se a consciência e a razão sempre ocuparam o lugar da esperança e da salvação no mundo Ocidental, se é esta a sua tradição, a psicanálise trouxe, inicialmente, uma desesperança quanto à possibilidade de domínio do que não é racional, com as noções do inconsciente e da sexualidade guiada pelo princípio do prazer. A pulsão de morte radicaliza o princípio pulsional. Ela também encontra certo apoio na vivência freudiana da destrutividade sem regra e da experiência da irracionalidade das guerras. $\mathrm{O}$ horror da Primeira Guerra Mundial, na qual Freud perdeu um filho, e os maus agouros com a Segunda Guerra Mundial, que obrigou ao exílio Freud e parte de sua família, teriam contribuído particularmente a primeira - para a afirmação do pessimismo freudiano e trouxe elementos para a postulação da pulsão de morte. Mas não se trata aí simplesmente de desilusão pessoal. As guerras mundiais fizeram pensar na derrocada do sonho Ocidental da regulação e bem-estar, principalmente se se considera a esperança depositada na ciência moderna que mostra, já em 1918, sua enorme capacidade de controle da natureza e, talvez residisse aí a esperança, das relações entre os homens. A pulsão de morte contribui, então, para a compreensão justa das relações dos sujeitos humanos entre si e com a cultura ou civilização, apontando o necessário preço que se paga para a "confortável" existência em sociedade, para a participação dos homens com valores comuns e para o somatório de suas ações em prol de todos. Paga-se com a renúncia à satisfação pulsional, seja com a renúncia e o adiamento da satisfação da pulsão sexual, seja com a internalização, mais uma vez, da pulsão agressiva e da destrutividade para si mesmo — "o voltar-se contra a própria pessoa”, destino pulsional que já fora anunciado por Freud (1915/1989i). O controle pulsional é a regra da civilização. 
Entretanto, a civilização, melhor para o caso será dizer, a cultura, também é o que apresenta ao sujeito os objetos da sua satisfação: objetos sexuais e objetos para a destrutividade. Assim, abre-se a perspectiva para a convivência fraterna, embora necessariamente ela não se imponha, nem seja absoluta e completa (Freud, 1912/1988h); como também se abre a possibilidade do desvio da destrutividade para o mundo externo (sob várias e diversas formas que não tenham por resultado a destruição da vida), livrando o sujeito, ao menos parcialmente, de atitudes de automortificações. Seja a agressividade necessária à sexualidade, seja a agressividade na conquista da natureza ou mesmo no progresso da ciência, ambas seriam formas da canalização da pulsão de morte para fora do próprio sujeito, dentre muitas outras formas. O benefício ou o malefício de tais saídas permanecerá com seus limites flutuantes, a depender da intensidade de tais visadas. É que para Freud, e para a psicanálise de modo geral, não há possibilidade de garantia ou de organização que seja seguramente boa em todos os sentidos para o sujeito, para seus próximos e para o mundo. A tensão é permanente e os diversos modos dessa relação são compromissos estabelecidos entre as forças que aí atuam.

Na perspectiva da clínica psicanalítica, a pulsão de morte e Eros trouxeram, cada uma a seu modo, possibilidades de apreensão e avanços significativos. Tais avanços não significam um ganho imediato e objetivamente apreensível para a cura psicanalítica. De fato, em certo sentido, a pulsão de morte expressa o pessimismo com o tratamento psicanalítico e sua crise, mais uma delas. Clinicamente, a reação terapêutica negativa e a impossibilidade da solução da transferência impuseram-se como dificuldades severas ao tratamento. A compulsão à repetição, que muito antes de ser uma conquista teórica mostrou-se como fenômeno na clínica, trouxe a compreensão da força efetiva da pulsão de morte no interior do psiquismo. Ela anuncia o princípio que escapa e está além do princípio do prazer, o de morte ou de autoaniquilamento. Nesse ponto, todo o instrumental psicanalítico parece falhar e a psicanálise viu-se obrigada a redimensionar suas pretensões terapêuticas, de modo ainda mais radical em comparação com o acontecido a partir da universalização do inconsciente, como acima discutimos. O inconsciente, cujo modelo é a neurose e o sonho, estaria ainda regido pelo princípio do prazer, desviado de seu propósito imediato pelo princípio de realidade, pela necessária adaptação do sujeito ao seu mundo físico e cultural. Podemos sugerir, sem muito transtorno para a compreensão psicanalítica e sem trair seus fundamentos básicos, que o psiquismo como tal permanece tendo como princípio o do prazer, mas a pulsão, esta "habitante", por assim dizer, do psiquismo e enraizada no corpo, rege-se pelo princípio da morte, de seu autoaniquilamento, da repetição sem fim e, aparentemente, sem o propósito do prazer.

Outro aspecto significativo para a clínica psicanalítica na perspectiva da pulsão de morte foram os desenvolvimentos sobre o masoquismo, o qual passa a ser compreendido, a partir daí, como originário, dele derivando-se formas específicas do masoquismo - o erógeno ("como condição a que se submete a excitação sexual"), o feminino ("como expressão da natureza feminina") e o moral ("como norma de conduta na vida") -, permitindo reconsiderar as formas dos obstácu- los ao tratamento psicanalítico: seja o gozo com a dor (com o sofrimento), seja o impossível da passividade (angústia de castração), seja o modo desta radical neurose chamada neurose de destino, respectivamente. Formas de obstáculos determinadas pelo princípio pulsional por excelência, o que quer dizer, obstáculos incontornáveis (Freud, 1924/1989a, p. 167, para as citações).

Green (1983/1988) avança na perspectiva freudiana, buscando articular o narcisismo com a pulsão de morte, apreensão que não estaria presente em Freud por ter, em alguma medida, negligenciado o narcisismo a partir da introdução da pulsão de morte. Com tal articulação, em outro trabalho, Green (2003/2005) sugere pensar a destrutividade dirigida ao objeto e a orientada para o interior do próprio sujeito. Para a primeira, dá evidências à agressividade que permitiria compreender o gozo do sádico por sua identificação com o masoquista; para a segunda, sugere a associação da pulsão de morte com o narcisismo, caracterizando a destrutividade como ação para o aniquilamento do narcisismo do objeto. $\mathrm{Na}$ agressividade, segundo podemos entender de Green, estaria presente o princípio do prazer em sua radicalização como gozo (conceito que toma de Lacan). Também aqui se identifica a máxima freudiana de que as pulsões de morte e Eros jamais aparecem completamente separadas uma da outra, mas que familiarmente se juntam na expressão dos comportamentos e das atitudes. Pode-se considerar que em todo fenômeno uma ou outra das pulsões sobressai. A identificação de que fala Green carrega o aspecto da assimilação do objeto, portanto, não sua destruição pura e simplesmente. Diversamente, na destrutividade do narcisismo está implicada a atitude de aniquilamento do objeto, sem consideração com seu gozo (como ao contrário se verificaria no sadismo). A destrutividade, assim, faz-se de uma radicalização suprema, a impossibilidade própria ao narcisismo de morte da consideração com o objeto - tratase da verdadeira e inescapável posição "ou ele ou eu”. Se, no inconsciente, tal como Freud (1900/1987a) o propôs na Interpretação dos sonhos, não haveria oposição efetiva, mas, sim, processos de compromisso entre o impulso de desejo e a força que o recalca, no caso da destrutividade, o "ou" de "ou ele ou eu” torna-se um índice de exclusão, de impossível compromisso. Os desenvolvimentos quanto ao narcisismo ganham, em Green (1983/1988), aspectos relevantes, com forte repercussão em diversas considerações da psicanálise contemporânea.

A recuperação que Green (1983/1988) propõe fazer do narcisismo, além do propósito de retomar considerações que não estariam presentes em Freud, segundo julga, também tem o objetivo de superar certos desenvolvimentos psicanalíticos após Freud que, dedicados às relações de objeto, excluíram o narcisismo (exemplos originários são oferecidos por Balint, 1968/1993; Fairbairn, 1952/1999) e as pulsões para a consideração dos processos de subjetivação. Os conceitos de narcisismo de vida e narcisismo de morte trazem perspectivas de avaliação de desenvolvimentos subjetivos contemporâneos. Sem desprezar seja o narcisismo, sejam as pulsões, Green, em sua longa obra, tem o objetivo de dar compreensão freudiana (mas um Freud relido criticamente) às chamadas psicopatologias contemporâneas: os depressivos, os borderlines, os casos limites, os narcisistas e os não-neuróticos, de modo 
geral. Trata-se, conforme explicitamente admitido por Green (2003/2005), de desenvolvimentos fortemente influenciados pela psicanálise francesa, diferente do que teria ocorrido com a americana e a inglesa, principalmente preocupadas com a psicologia do ego, as considerações com respeito ao self como personalidade total, a destrutividade herdada dos kleinianos, que exclui a sexualidade, as fortes considerações com respeito às relações de objeto promovidas a partir de um ego central e total, as considerações quanto aos mecanismos defensivos do ego (Ana Freud) etc.

A articulação entre as pulsões e o narcisismo permite não somente a compreensão radical da destrutividade que visa $o$ narcisismo do objeto, como acima o apontamos, mas também os destinos de mortificação do próprio sujeito, em estados fortemente depressivos, como os significados pela noção da "mãe morta". Podemos adicionar à articulação entre pulsão de morte e narcisismo, as considerações freudianas sobre o masoquismo moral, articulando uma forma de culpabilidade (culpa inconsciente) que inviabiliza, ou quase, os progressos de uma psicanálise, antes tendo tornado repetitivos os fracassos dos sujeitos nas diversas tentativas de assenhoramento, embora parcial, de suas existências. Estado de culpabilidade profunda e basal, impedindo a apropriação da própria liberdade de escolha ou liberdade com o seu desejo. Estado este que sofre o sujeito, impossibilitado sequer de perceber a possibilidade de outra conduta ou atitude na vida, parafraseando aqui Freud (1924/1989a). Não se tratam necessariamente de casos depressivos, mas de uma crença não completamente consciente do destino duro e do esforço que a vida demanda, "dobrado em comparação com os outros", comenta um analisando, como também a certeza profundamente enraizada da impossível felicidade, mesmo quando a experiência efetiva possa ser considerada, para olhos externos, como de felicidade ou de realização de desejos. O mundo se torna um mar de obstáculos, quotidianamente apresentados; "um leão por dia", já anuncia o ditado. Não são necessariamente depressivos ou borderlines tais quadros, mas gravíssimas neuroses obsessivas compulsivas, por exemplo. A última teoria pulsional de Freud (1920/1989e), revisitada por muitos outros além de Green (1983/1988) e na esteira deste, se não traz instrumentos para essas formas de tratamento, mostra sua inflexibilidade aos chamados procedimentos padrão e pode justificar a necessidade que alguns psicanalistas sustentam de um enquadre modificado (Figueiredo, 2008; Winnicott, 1969/1994), embora o façam a partir de outra base que não a pulsional, exceto, certamente, se considerarmos a posição de Green e seus seguidores.

Para completar a teoria pulsional freudiana, precisamos ainda de algumas palavras sobre Eros. Eros engloba a pulsão sexual e a de autopreservação, conduzindo-nos a pensar, como Green (1997/2000) o sugere, tratar-se de uma pulsão de amor, a significar uma pulsão que se entende e estende como uma cadeia inteira: desde sua fonte somática, seu impulso, passando pelos diversos desvios e destinos, até alcançar o objeto da satisfação e, novamente, sua experimentação no corpo próprio como prazer. Eros, então, rigorosamente supõe o objeto; e na proposta de Green, perde sentido, dessa maneira, a exclusão da pulsão sexual para se pensar as relações de objeto, como se estabeleceu tradicionalmente considerar desde Fairbairn (1952/1999), que substitui a busca do prazer pela busca do objeto, desprezando as pulsões e seus destinos. Eros modifica o postulado freudiano inicial da indiferença do objeto para a satisfação pulsional. No entanto, não devemos esquecer que Freud (1918/1988d; 1912/1988f; 1910/1988g) já considerara a especificidade do objeto quando discutiu a psicologia do amor. Se a pulsão de morte conduz à raiz o impossível da cura analítica, Eros abre a perspectiva de sua consideração numa forma de vínculo que nem garante toda a satisfação desejada nem abandona toda perspectiva de vínculos satisfatórios, embora a pulsão de morte permaneça como parâmetro último do limite da análise.

Seguindo o propósito de nos estender além de Freud, entre as diversas interpretações ou compreensões da pulsão de morte, destacamos a de Melanie Klein (1882-1960), autora que também trouxe contribuição decisiva para a compreensão das relações de objeto com a noção de mundo interno (sua ascendência faz-se direta sobre Winnicott e Bion, por exemplo, e sobre uma longa tradição kleiniana que se desenvolveu na psicanálise inglesa) ${ }^{6}$. No que diz respeito à pulsão de morte, a contribuição de Klein $(1975 / 1996)^{7}$, em traços largos, foi para entendê-la como agressividade, inicialmente voltada para o próprio sujeito e, depois, para o objeto, segundo a posição no desenvolvimento. Na posição mais arcaica do desenvolvimento, esquizo-paranóide, a agressividade estaria voltada essencialmente para o próprio sujeito, sendo ela responsável pela situação esquizoide e persecutória que caracteriza tal posição. Na posição depressiva, a agressividade se dirige contra o objeto de qual amor depende o sujeito, sendo-lhe característica a culpa pela fantasia de destruição do objeto. A culpa pode ser entendida como uma ação da pulsão de morte, somente que mediada pelo objeto, supondo uma maior integração do sujeito em comparação com a desintegração da posição anterior.

A clínica influenciada por Melanie Klein está especialmente voltada para a psicose e para a psicanálise de criança. Tem o objetivo geral de conduzir os sujeitos da análise para uma maior integração, o que significa levá-lo à posição depressiva. Faz uso da identificação projetiva (Strachey, 1934) e da contratransferência como instrumento de interpretação (Heimann, 1949/1989). Segundo Grosskurth (1986/1992, p. 404), Paula Heimann teria, mais ou menos a despeito de Klein, colaborado decisivamente para a conformação do kleinismo que se fez presente e se expandiu na International Psychoanalytical Association (IPA). Para o entendimento do kleinismo hoje, parece-nos adequado dizer que sua concepção encontra-se matizada por aqueles que se convencionou chamar de neo-kleinianos, que, em resumo, buscam estabelecer relações entre Klein e outras tradições da psicanálise. Por exemplo, Bion, que estabelece relações entre Klein e Freud sem passar por Anna Freud (Green, 1979/2004). Nessa

6 Para exemplo de sua força ainda na atualidade, veja-se os autores representados em Spillius (1988/1990, 1988/1991). No Brasil, particularmente, ver Cintra e Figueiredo (2004) e Figueiredo (2007), dentre outros.

7 A contribuição kleiniana é muito ampla e sua teoria e clínica, complexa e profunda. Não há como retomá-la aqui. A seguir, trazemos concepções desenvolvidas ao longo de diversas leitura de alguns de seus textos e de autores que a comentam. Não vamos citar trabalhos que tratam de temas específicos da autora. As obras completas de Klein estão publicadas pela Imago. 
perspectiva, sugerimos incluir Luís Claudio Figueiredo entre os neo-kleinianos, embora ele mesmo rejeite incluir-se em alguma escola, antiga ou nova.

Figueiredo (2007; ver também Cintra \& Figueiredo, 2004), nas abordagens da clínica e obra de Melanie Klein, numa atitude que caracteriza muito o pensamento psicanalítico contemporâneo mais avançado, vai além de Klein e propõe atravessar os paradigmas das diversas escolas, dos diversos pensamentos e das experiências psicanalíticas de psicanálise, para costurar o que os caracteriza fundamentalmente. Tomando Freud como aquele que está sempre presente, pela herança que dele recebemos, mas também pela retroação de nossas experiências e reflexões contemporâneas sobre a sua obra, Figueiredo propõe ricas e atualizadas leituras de Melanie Klein, atravessadas pelas conquistas freudianas, winnicottianas e bionianas, dentre outras mais recentes. Aos nossos olhos se configura que a base de incursão de Figueiredo, a base de onde parte seu esforço de atravessamento dos paradigmas, em busca de uma teoria geral do cuidar de base psicanalítica (Figueiredo, 2009), é Melanie Klein, sem desprezar a importância capital que dá a cada autor que toma com a finalidade de penetrar e expor os paradigmas que alimentam seus pensamentos e suas clínicas. É, por exemplo, o que ele faz ao articular em psicanálise a partir da noção kleiniana fundamental de phantasias inconscientes (Figueiredo, 2009, p. 23-52). Com essa noção kleiniana, sugere estabelecer a mediação entre o soma, o mental e o mundo, tanto no suposto sentido progressivo que a sequência de tais instâncias ensejam, como também no sentido regressivo. Assim, as phantasias inconsciente estão profundamente ligadas à pulsão, são sua representação psíquica, estão vinculadas ao ego, em sua função integradora com o mundo. Também nelas encontram-se os objetos internos, que foram introjetados e podem ser projetados. Enfim, o autor busca articular os ganhos do pensamento e da clínica kleiniana com a freudiana e também a winnicottiana, na medida em que salienta o caráter paradoxal das phantasias. Observe-se que a grafia de phantasia com " $p h$ ” vem da tradição inglesa para diferenciar tais elementos do psiquismo da fantasia de desejo introduzida por Freud (1900/1987a) e, como se sabe, retomada e desenvolvida por Lacan (1966/1998).

\section{Atualidade da Psicanálise}

Seguindo a sugestão de estruturação do artigo, algumas palavras são necessárias para avançar um pouco mais na apreensão da psicanálise na atualidade, entendida de 1985 aos dias de hoje, e propor a compreensão de linhas de desenvolvimentos que julgamos ser razoável acreditar que aconteçam.

Marco significativo para a psicanálise no Brasil nos anos 80 do século passado, foi certamente a introdução de modo mais enfático da psicanálise lacaniana. As primeiras leituras sistemáticas de Lacan $(1966 / 1978)^{8}$ e primeiros comentaristas e divulgadores de sua obra começam a surgir. De imediato,

8 Essa foi a primeira edição, parcial, no Brasil, da obra de Lacan. Uma obra completa, em português, somente apareceu em 1998. Desde então, seus Seminários têm sido paulatinamente editados e traduzidos.
Lacan encontrou forte eco em círculos de psicanalistas vinculados de algum modo à reflexão acadêmica, o que não seria certamente difícil de entender, embora não caiba aqui explorar tal aspecto. Mas, uma psicanálise, como a presente na obra desse autor, que destacadamente favoreça sua leitura como pensamento, que facilmente conduz para longe da clínica psicanalítica quando sob a verve de um olhar filosófico, por assim dizer, pode sugerir o entendimento da difusão especializada que o lacanismo encontrou entre nós. Lacan, na condição de dissidente da IPA, abriu a possibilidade pública da formação psicanalítica, com promessa de uma releitura rigorosa de Freud, embora crítica. A psicanálise, assim tomada, possui todos os ingredientes para despertar o interesse de reflexões acadêmicas e para alavancar vocações até mesmo inicialmente tímidas para a psicanálise. Evitava-se, desse modo, as rigorosas exigências para a formação do psicanalista, muitas delas de caráter predominantemente formal, das sociedades vinculadas à IPA. Acontecia, por exemplo, com a permissão de ingresso, restrita que era aos médicos, o que fazia prevalecer a ideia de uma formação oficial profissionalizante, além de excluir anseios de psicólogos e outros formados em ciências humanas. Tais exigências eram estranhas ao lacanismo. Por esse motivo, muitos dos hoje psicanalistas se aventuraram por uma formação no meio acadêmico, não sistematizada em todo, se não no aspecto teórico da psicanálise. As perspectivas clínicas e técnica tiveram, por muito tempo, para esses formandos, um caráter menos sistemático, como análises pessoais variantes quanto à frequência e ao tempo de análise, supervisões esporádicas e a autorização como psicanalista deixada por conta do próprio sujeito, como proposto por Lacan, assumida muitas vezes de modo leviano, ou, pelo menos, ao "gosto do freguês", como se diz. É claro que tal situação não impediu formações vigorosas e rigorosas, nem a interpretação e divulgação responsável do texto lacaniano. Uma porta (ou muitas) se abriram para a divulgação da psicanálise, mais ou menos coincidente com o momento que a psicanálise oficial (representada pelas sociedades vinculadas à IPA) pareceu perder fôlego e ver minguar seus candidatos.

Na década seguinte, a configuração geral da psicanálise no Brasil parece mudar. Diversos egressos do movimento lacaniano permaneceram ou vieram a engajar-se nas sociedades ligadas à IPA. As regras dessas sociedades começaram a ser criticadas no seu próprio interior, de tal modo que hoje se pode encontrar diversidade e flexibilidade em aspectos que eram muito formais e mesmo essenciais à formação anteriormente considerada muito rígida. Em sequência, as associações lacanianas e as vinculadas à IPA multiplicaram-se, por desentendimentos internos teóricos, políticos e mesmo éticos.

No que tange à psicanálise em seu desenvolvimento teórico e clínico, a era das escolas, como se gosta de afirmar, tem encontrado seu fim nos últimos anos. Lacanianos leem outros psicanalistas, deixando um tanto de lado seus sectarismos (consideraram que Lacan lia outros, inclusive psicanalistas, que não somente Hegel, de segunda mão). De tal maneira, aconteceu que muito recentemente encontramos psicanalistas de formação lacaniana interessados nas relações primitivas de objeto, dedicando-se a observações (coisa a causar espanto se nos anos 80 e parte dos 90) de relações mãe-bebê, por exemplo. Tendo, com isso, em muitos casos, a dignidade de ler Klein, Winnicott e outros. 
Não menos importante para a formação do panorama atual da psicanálise no Brasil foi a influência de lacanianos desgarrados (permitam-nos dizer assim, por economia), em nossas reflexões clínico-teóricas, como, por exemplo, Green, Laplanche, Pontalis, Aulagnier, Fedida, o casal Mannoni etc. A psicanálise de origem francesa que veio afinal compor o panorama da psicanálise no Brasil teve a vantagem de se mostrar muito mais flexível à diversidade do pensamento psicanalítico como um todo. Green e os que seguem a trilha por ele aberta ou que simplesmente nele se inspiram constituem exemplos importantes na perspectiva de abertura e diversidade. Convivem, por vezes se aproximam em aspectos específicos, mas, principalmente, deixam-se tomar uns aos outros de modo crítico e, muitas vezes, produtivo, contribuindo para a apreensão e compreensão da clínica psicanalítica. Tais autores tiveram o mérito de deixar a psicanálise inglesa e americana aproximar-se da psicanálise francesa muito inspirada que era em Freud, até mesmo por força do projeto lacaniano. Essa psicanálise francesa parece finalmente menos sectária que a anglo-saxônia. Como afirma Etchegoyen (2005), o próprio Green teria sido muito tardiamente reconhecido pelos psicanalistas de língua inglesa, por exemplo.

Outro caso curioso é o de Winnicott, autor tão influente e atualmente assimilado que se custa a acreditar que sua presença séria e desenvolta tenha pouco tempo entre nós. Também entre os ingleses, ele não esteve em primeira linha logo tenha surgido. Enfrentou adversidade com os movimentos ou as escolas kleiniana e ana-freudiana, até conseguir se consolidar como grupo independente. Nas sociedades ligadas à IPA no Brasil, o nome de Winnicott foi, por muito tempo, quase desconhecido. Predominava uma psicanálise kleiniana do tipo "puro-sangue" (Figueiredo, 2009 , p. 23), inflexível em suas certezas, ou mesmo uma psicanálise bioniana, curiosamente muitas vezes pensada e praticada simultaneamente, independente de Freud e Klein, seus inspiradores mais diretos. Enfim, algumas tentativas mais ou menos bem sucedidas têm tirado a psicanálise dos sectarismos escolares, por vezes como desejo ou propósito ainda não consolidado. De qualquer maneira, não será mais alienado das sociedades ligadas à IPA o pensamento que se interessa pelos freudianos, kleinianos, lacanianos, pelos que se voltam para as teorias das relações de objeto, para as teorias da pulsão e seus destinos, pelos que se dedicam à análise padrão e os que buscam modificações do enquadre para atender novas demandas, ou novos sintomas, ou novas configurações psíquicas. No entanto, o risco do ecletismo e do reducionismo e a presença de resquícios das escolas e da fidelidade cega a mestres não deixam o quadro ser tão benevolente como o que erroneamente se pode induzir do que viemos de expor. ${ }^{9}$

\section{Futuro da Clínica Psicanalítica}

Isso enseja indicarmos alguns vetores de desenvolvimento futuro da psicanálise no Brasil, que têm o caráter de apontar o que se pode esperar do que aí está, mas

9 Confira a instigante coleção de autores contemporâneos, de três dos quatro cantos do mundo, organizada por Green (2001/2003b). também a isso agregado, expressar nossa esperança de acontecimento.

Ao longo da primeira parte deste texto, já viemos nos achegando à reflexão psicanalítica que consideramos mais relevantes na atualidade e fizemos até mesmo um pouco de história, história de vetores, de matrizes, de ideias diretrizes, não tendo sido, nem foi este o nosso propósito, o traçado da história do movimento psicanalítico de modo amplo e que tivesse alguma pretensão de completude. Simplesmente apresentamos alguns balizamentos do pensamento psicanalítico e de suas reflexões clínicas mais predominantes. Assim o fizemos adotando uma metodologia específica. Tomamos o movimento da obra freudiana e a partir dele, de suas variações, buscamos indicar desenvolvimentos posteriores mais ou menos diretos, como também aqueles que daí se afastaram, sem pretender cobrir todo o campo da psicanálise. Com isso esperamos ter conseguido trazer um panorama original e atual da psicanálise para a comemoração dos 25 anos de existência da revista Psicologia: Teoria e Pesquisa, veículo que deu lugar a várias das áreas e subáreas da psicologia e da psicanálise, mesmo que esta última não tenha ocupado devidamente o espaço que lhe poderia ser oferecido. Considerando, portanto, a atualidade da psicanálise de alguma maneira já traçada, sugerimos pensar seu destino em três aspectos nos quais desejamos ser breves: teórico-clínico, áreas de atuação e relações com a cultura.

\section{Aspecto teórico-clínico}

A exposição que fizemos nos conduz a pensar em três modelos do pensamento psicanalítico, cujos dois deles foram nomeados, e dos quais talvez se possa apreender a diversidade da clínica. Esses modelos seriam: o neurótico, o paranóico (este não foi nomeado, mas foram apresentados os seus fundamentos) e o melancólico. Antes de resumir cada um deles e o que sugerem para o futuro da psicanálise, convém observar que tais modelos não são estanques e que seus fundamentos se entrelaçam em muitos aspectos. Eles são aqui usados como guias, tão somente.

Vinculam-se ao modelo neurótico a sexualidade e o inconsciente. Isso significa dizer das preocupações iniciais com a pulsão, a pulsão sexual e sua oposição à adaptação do sujeito na realidade; o princípio do prazer, como o que determina os processos primários (inconsciente), e o princípio de realidade, para os processos secundários vinculados ao eu. O modelo diz do desejo, submetido ao processo do recalcamento e do conflito. Clinicamente, ganha importância a linguagem; na verdade, as considerações do inconsciente a partir da Interpretação dos sonhos (Freud, 1900/1987a) conduzem a certo otimismo com respeito à linguagem, no qual Lacan teria se inspirado, como já o observamos com Kristeva (1996). A associação livre e a interpretação resumem o método do tratamento psicanalítico. Considerações com o Complexo de Édipo e de castração determinam os aspectos metapsicológicos das psiconeuroses, mas também do desenvolvimento dito normal. Implicam-se as escolhas do objeto da satisfação pulsional, da identificação sexual e das considerações quanto à masculinidade e feminilidade. Nesse amplo âm- 
bito do modelo neurótico situa-se o que se convencionou chamar de psicanálise padrão.

Na perspectiva desse modelo, certamente continuará a vigorar o movimento padrão da psicanálise, talvez aí se expressando o que se poderia entender mais estritamente como psicanálise, inclusive acompanhando Winnicott (1979/1983), que supõe a análise modificada como distinta da psicanálise propriamente, embora devesse ser empreendida por psicanalistas. As discussões sobre psicoterapias de base psicanalítica parecem poder se desenvolver sobre outra base que não a da simples distinção em relação à psicanálise padrão. Talvez não fiquem tão distintas as duas modalidade de tratamento, a psicanalítica propriamente e a psicoterapia de base psicanalítica. Green (2003/2005) sugere que o enquadre da psicanálise deva permanecer no psicanalista, como internalizado por este, mesmo em situações de psicoterapia, onde ele é fisicamente distinto. $\mathrm{O}$ enquadre de que se trata não se esgota na disposição física do ambiente, mas envolve o ambiente emocional ou psíquico, a associação livre tomada em atenção flutuante e a reveriê do analista, que permite a interpretação. Mas, também, o enquadre modificado na psicoterapia permite o holding, o asseguramento para a regressão de que falam os teóricos da relação de objeto desde Winnicott (1964/1994), o enquadre para o fim da "provisão ambiental especializada" (p. 78). Essa situação já se afastou bastante da psicanálise padrão e se justifica, seja para o atendimento de demandas específicas, seja como modificação necessária para atender a uma exigência do cuidar de modo geral. Nessa direção, com propostas de articulações entre o enquadre padrão e o modificado, deve caminhar a reflexão psicanalítica (ver, por exemplo, Figueiredo, 2008).

Para o modelo que designamos paranóico, o que está em questão é, duplamente, a constituição do eu como instância e as formas do investimento amoroso nos objetos. A inspiração de que nos servimos é o caso apresentado por Freud (1911/1987b), do Presidente Schreber. Nele se conjugam simultaneamente as questões do destino pulsional, como amor homossexual, e o desenvolvimento do eu simultaneamente como personalidade e instância. Como se sabe, Freud jamais abandonou a teoria pulsional e, particularmente, a pulsão sexual na consideração metapsicológica e clínica dos casos. No caso Schreber, como anunciando a posterior proposta de Green (1997/2000), unem-se as considerações da pulsão e seu vínculo com o objeto. Essa articulação, que inclusive permitirá desenvolver já em Freud considerações sobre os vínculos grupais baseados nos investimentos libidinais e seus processos por meio da identificação, parece-nos extremamente importante para o desenvolvimento futuro da psicanálise. Isso porque permite recuperar exatamente o seu fundamento pulsional na compreensão, ainda que parcial, dos casos e das situações que envolvem as relações de responsabilidade com o outro. Aspectos como os da agressividade descontrolada e sem motivo aparente necessitam da reflexão psicanalítica, além do assentimento com respeito à importância do objeto e seu par, o self. Isso quer dizer, considerações além das que tomam estritamente as configurações do self e da personalidade em seu estado defensivo. O modelo paranóico permite introduzir ou recuperar para grande parte ainda da psicanálise contemporânea e, portanto, para seu futuro, a força que move os sujeitos, os aspectos da economia psíquica para a compreensão dos comportamentos agressivos e mesmo destrutivos. Questões relacionadas ao gozo podem então contribuir para o entendimento dos comportamentos antissociais. Sem necessariamente aderirmos em sua totalidade ao propósito anunciado em Cadeias de Eros, Green (1997/2000) parece-nos outra vez expressar, no sentido que estamos discutindo, o mais significativo desenvolvimento da psicanálise, exatamente não desprezando o aspecto pulsional, amoroso e agressivo para a abordagem dos considerados novos casos - casos limites.

O modelo melancólico, amplamente acima discutido, reintroduz de modo mais preciso as questões dos limites. O eu novamente se encontra no centro da discussão. Mas trata-se agora de dar ênfase em dois outros aspectos, o do narcisismo, isto é, do investimento libidinal e destrutivo do próprio eu, e o dos limites da constituição do eu em face dos objetos. Os limites do psiquismo, do eu, do self, das instâncias psíquicas e da totalidade dos sujeitos, e a diferenciação entre o sujeito e o objeto, entre o eu e os objetos (objetos da pulsão, objetos da necessidade), banhados pelas questões pulsionais, sexuais e destrutivas, parecem se constituir tarefas ainda a serem completadas, entretanto já iniciadas. ${ }^{10} \mathrm{O}$ desenvolvimento da metapsicologia dos limites e da clínica diferenciada sem aderir a uma concepção, seja unificada, seja eclética, parecenos constituir tarefa que não se esgotou e espera pelo futuro da psicanálise.

\section{Áreas de atuação}

As discussões sobre o enquadre acima indicadas nos permite avançar, embora não seja a mesma coisa, na reflexão sobre as áreas onde tem lugar a psicanálise e atuam os psicanalistas. $\mathrm{O}$ empreendimento de psicoterapias, tendo por base a psicanálise e praticadas por psicanalistas, é um indício da amplitude que ganhou nos últimos tempos a presença da psicanálise em outros campos, áreas e situações que não os tradicionalmente conhecidos do consultório particular. Winnicott (1984/2005) novamente teve papel inovador, não somente modificando a situação de análise, mas também introduzindo a psicanálise no cuidado mãe-bebê, no atendimento de órfãos de guerra fora dos consultório, em hospitais e em ambientes da assistência social. No Brasil, a psicanálise entra nos hospitais, nas varas judiciárias da infância e da família, no atendimento a jovens que cumprem medidas socioeducativas, no acompanhamento terapêutico (a que chamo carinhosamente de psicanálise de meio fio), nas universidades (tanto nos atendimentos psicoteráticos em seus ambulatórios nos cursos de psicologia, por exemplo, como no ensino e na pesquisa universitárias). A maior parte dessas situações engloba participações multidisciplinares do psicanalista.

Em todas essas condições e outras que nos escapam de citar, o enquadre está profundamente modificado em relação ao que se chama padrão. A psicanálise aí se apresenta não somente como teoria para o entendimento do que se trata.

10 Dentre muitas outras abordagens, vale consultar: Cardoso (2004) e Cardoso e Garcia (2010). 
Ela também participa, como lembrado acima, como enquadre internalizado pelo analista, devido à sua experiência com a análise pessoal. Também está presente como procedimento de escuta do outro e da intervenção que não seja simplesmente pedagógica ou corretora, mas uma intervenção que tenha o propósito de auxiliar reorganizações subjetivas duráveis, menos preocupada com mudanças de comportamentos parciais ou específicos. A compreensão do inconsciente, do pulsional e da constituição de holding são bases para a disposição dos psicanalistas que atuam em tais circunstâncias. Podemos aderir ao proposto por Figueiredo (2009), que diz da constituição de uma teoria geral do cuidar de base psicanalítica, e acrescentar a constituição de uma situação geral do cuidar de base psicanalítica. ${ }^{11}$ Muito a propósito dessas questões, renovam-se as reflexões sobre a situação analisante, que significa a preocupação com a situação analítica, o enquadre que tem força analisante, que trata. Problematização feita ao enquadre tradicional e aos outros que a psicanálise vem conquistando e ajudando a construir, como os acima nomeados (Donnet, 2001; Fédida, 1995/1996; Roussillon, 2005).

\section{Relações da psicanálise com a cultura}

As relações da psicanálise com a cultura ou sociedade, de várias maneiras pensadas e não raramente dedicadas a aspectos específicos (psicanálise e arte, por exemplo), encontram desde Freud reflexões significativas. Freud (1939/1986c, 1930/1988a, 1927/1988c, 1919/1988e, $1912 / 1988 \mathrm{~h}, 1921 / 1989 \mathrm{~g}$ ) aventurou-se a estabelecer as condições dos agrupamentos humanos, da origem das organizações sociais e os efeitos da vida em sociedade sobre os indivíduos. Também não se furtou à análise de produtos culturais, visando investigar a subjetividade do autor e estabelecendo as condições de realização de tais obras (e.g., Freud, 1907/1986b, 1914/1988b, 1942/1989f). Após Freud, mais ou menos próximo da esteira por ele aberta, já se pensou a psicanálise como uma teoria da socialização, tomando-a como teoria crítica; buscaram-se as relações de dependência mútua entre a psicanálise e a sociedade (ver as coletâneas preparadas por Figueira, 1981, 1985, 1988); estabeleceram-se as determinações sociais sobre as constituições subjetivas à luz da psicanálise; discutiramse as relações entre arte e psicanálise (e.g., Birman, 1988, 1999; Carvalho \& Viana, 2009; Costa, 2003; Gabriel, 1988; Goldenberg, 1997; Guimarães \& Celes, 2007; Kehl, 1996, 2002; Lorenzer, 1973; Mezan, 1990; Rivera \& Safatle, 2006; Rouanet, 1983; Slavutzky, 1983; Slavutzky \& Kupermann, 2005; Souza, 1999; Viana, 2007; Zavaroni \& Celes, 2004) etc.

Outros estudos e reflexões psicanalíticos bastante importantes, cuja bibliografia é vastíssima, diz respeito ao estabelecimento das determinações da cultura e sociedade sobre as constituições subjetivas, com o propósito de explicar, compreender ou descrever as novas demandas de psicanálise, os novos sintomas, as novas configurações subjetivas ou mesmo psicopatológicas e, com isso, justificar outras teorias

11 Certamente esse acréscimo não é alheio ao propósito de Figueiredo (2009), embora não esteja assim explicitado. (metapsicologias) e mudanças no tratamento psicanalítico, como também as incursões da psicanálise em situações que não eram originariamente campos de sua atuação. Certamente, a reflexão de justificativa da psicanálise e de suas modificações, por estranho que isso pareça, terão continuidade no futuro próximo e mais longínquo, pois muito da psicanálise que se pratica hoje (teórica e clinicamente) está fortemente alicerçada na apreensão de profundas mudanças nas estruturações psíquicas dos humanos advindas com a modernidade tardia, a pós-modernidade e a contemporaneidade.

Por fim, mas não menos importante, gostaríamos de apontar um aspecto tradicional da psicanálise que se encontra na base de sua origem, foi esquecido e negligenciado, mas retorna com ensaios de sua inserção na reflexão psicanalítica contemporânea, justificando sua pertinência e a perda para a especificidade da psicanálise advinda de seu alheamento, como também a perda para a compreensão dos homens em seu mundo. Trata-se do aporte sobre as pulsões (de morte e de vida) e, particularmente, a sexualidade e seu papel fundamental na estruturação psíquica (e.g., André, 1995/1996; André \& cols., 2007; André \& Chabert, 2008/2008; Birman \& Nicéas, 1988; Bleichmar, 2007; Celes, 1995, 2005b, 2006, 2007, 2009; Jorge, 1996; Laplanche, 1988/1987; McDougall, 1989/1991, 1998; Parsons, 2002; Pontalis, 2000; Schaeffer, 2008). As questões com respeito à perversão, agressão e destrutividade, quanto ao gozo e ao prazer, podem ser resgatadas para a compreensão da situação dos sujeitos no mundo contemporâneo, de modo geral, mas, principalmente, com respeito à singularidade de cada sujeito em sua vida quotidiana.

\section{Referências}

Abraham, N., \& Törok, M. (1987). L'écorce et le noyau. Paris: Flammarion.

André, J. (1996). As origens femininas da sexualidade (V. Ribeiro, Trad.). Rio de Janeiro: Jorge Zahar. (Trabalho original publicado em 1995)

André, J., Baldacci, J.-L., Suchet, D., Dreyfus-Asséo, S., Guyomard, P., \& Yi, M.-K. (2007). La sexualité infantile de la psychanalyse. Paris: Presses Universitaires de France.

André, J., \& Chabert, C. (2008). O esquecimento do pai. São Paulo: EDUSP. (Trabalho original publicado em 2008)

Balint, M. (1993). A falha básica - aspectos terapêuticos da regressão (F. F. Settineri, Trad.). Porto Alegre: Artes Médicas. (Trabalho original publicado em 1968)

Bezerra Jr., B., \& Ortega, F. (2007). Winnicott e seus interlocutores. Rio de Janeiro: Relume Dumará.

Bion, W. R. (1994). Estudos psicanalíticos revisados (W. M. M. Dantas, Trad.). Rio de Janeiro: Imago. (Trabalho original publicado em 1967)

Birman, J. (1988). Percursos na história da psicanálise. Rio de Janeiro: Bookaria Taurus.

Birman, J. (1999). Mal-estar na atualidade. A psicanálise e novas formas de subjetivação. São Paulo: Civilização Brasileira.

Birman, J., \& Nicéas, C. A. (1988). A ordem do sexual. Rio de Janeiro: Campus.

Bleichmar, S. (2007). Paradojas de la sexualidad masculina ( $1^{\mathrm{a}}$ ed.). Buenos Aires: Paidós. 
Cardoso, M. R. (2004). Limites. São Paulo: Escuta.

Cardoso, M. R., \& Garcia, C. A. (2010). Entre o eu e o outro: espaços fronteiriços. Curitiba: Juruá.

Carvalho, M. T. P., \& Viana, T. d. C. (2009). Tornos e retornos do sujeito contemporâneo - reflexões artística e psicanalítica. Pulsional: Revista de Psicanálise, 22, 8-19.

Celes, L. A. M. (1994). A história e o estranho. Cadernos de Subjetividade, 2, 37-48.

Celes, L. A. M. (1995). Sexualidade e subjetivação: um estudo do Caso Dora. Brasília: Universidade de Brasília.

Celes, L. A. M. (2005a). Psicanálise é trabalho de fazer falar, e fazer ouvir. Psychê, $I X, 25-48$.

Celes, L. A. M. (2005b). Uma herança quase esquecida de Freud: a sexualidade infantil e suas injunções. Alter - Jornal de Estudos Psicodinâmicos, 24, 65-82.

Celes, L. A. M. (2006). Teoria da libido e teoria das relações de objeto: confronto e aproximações? Pulsional: Revista de Psicanálise, XIX, 5-13.

Celes, L. A. M. (2007). "Dora" contemporânea e a crise terapêutica da psicanálise. Psicologia Clínica, 19, 137-154.

Celes, L. A. M. (2009). Pela hora da morte. Em V. Zanello, C. Carneiro \& M. N. Campos (Eds.), Fronteiras em psicanálise (pp. 251-265). Guarapari: Ex Libris.

Celes, L. A. M., Alves, K. C. M., \& Santos, A. C. G. d. (2008). Uma concepção psicanalítica de personalidade: teoria das relações objetais de Fairbairn. Psicologia em Estudo (Maringá), 13, 53-61.

Celes, L. A. M., Santos, A. C. G. d., \& Alves, K. C. M. (2006). Teoria das relações de objeto em Freud e Fairbairn. Revista MalEstar e Subjetividade, VI, 291-310.

Cintra, E. M. d. U., \& Figueiredo, L. C. (2004). Melanie Klein. Estilo e pensamento. São Paulo: Escuta.

Costa, J. F. (2003). Violência e psicanálise ( $3^{\mathrm{a}}$ ed.). Rio de Janeiro: Graal.

Donnet, J.-L. (2001). A regra fundamental e a situação de análise (M. Pereira, Trad.). Revista Brasileira de Psicanálise, 35, 227-242. (Trabalho original apresentado em 2001 na Conferência Plenária do XLII Congresso Internacional de Psicanálise, Nice, França)

Etchegoyen, H. (2005). Preface. Em G. Kohon (Ed.), The dead mother. The work of André Green (pp. xi-xiii). London Routledge.

Fairbairn, W. R. D. (1999/1952). Psychoanalytic studies of the personality. London: Routledge.

Fédida, P. (1996). O sitio do estrangeiro (E. B. P. Leite, M. Gambini \& M. Seincman, Trads.). São Paulo: Editora Escuta. (Trabalho original publicado em 1995)

Figueira, S. A. (1981). O contexto social da psicanálise. Rio de Janeiro: Francisco Alves.

Figueira, S. A. (1985). Cultura da psicanálise. São Paulo: Brasiliense.

Figueira, S. A. (1988). Efeito PSI. A influência da psicanálise. Rio de Janeiro: Campus.

Figueiredo, L. C. (2000). Subjetivação e esquizoidia na contemporaneidade: questões metapsicológicas. Cadernos de Psicanálise, 16, 13-32.

Figueiredo, L. C. (2007). A clínica psicanalítica a partir de Melanie Klein. O que isto pode significar? Jornal de Psicanálise, 39, 125-150.

Figueiredo, L. C. (2008). Novas considerações sobre implicação e reserva. As posições do analista na análise padrão e na análise modificada segundo Winnicott. Em L. C. Figueiredo \& N. Coelho Júnior (Eds.), Ética e técnica em psicanálise (2ª ed.) (pp. 107-122). São Paulo: Escuta.
Figueiredo, L. C. (2009). As diversas faces do cuidar: novos ensaios de psicanálise contemporânea. São Paulo: Escuta.

Forrester, J. (1980). Language and the origins of psychoanalysis. New York: Columbia.

França, M. I. R. F. (1996). Ética, psicanálise e sua transmissão. Petrópolis: Vozes.

Freud, S. (1986a). Construcciones en el análisis. Em J. Strachey (Ed.), Obras completas, Vol. 23 (J. L. Etcheverry, Trad.) (p. 255ss.). Buenos Aires: Amorrortu. (Trabalho original publicado em 1937)

Freud, S. (1986b). El delirio y los sueños en la 'Gradiva' de W. Jensen. Em J. Strachey (Ed.), Obras completas, Vol. 19 (J. L. Etcheverry, Trad.) (p. 1ss.). Buenos Aires: Amorrortu. (Trabalho original publicado em 1907)

Freud, S. (1986c). Moisés y la religión monoteísta. Em J. Strachey (Ed.), Obras completas, Vol. 23 (J. L. Etcheverry, Trad.) (p. 1ss.). Buenos Aires: Amorrortu. (Trabalho original publicado em 1939)

Freud, S. (1987a). La interpretación de los sueños. Em J. Strachey (Ed.), Obras completas, Vol. 4 -5 (J. L. Etcheverry, Trad.) (p. 1ss.). Buenos Aires: Amorrortu. (Trabalho original publicado em 1900)

Freud, S. (1987b). Puntualizaciones psicoanalíticas sobre un caso de paranoia (Dementia paranoides) descrito autobiográficamente. Em J. Strachey (Ed.), Obras completas, Vol. 12 (J. L. Etcheverry, Trad.) (p. 1ss.). Buenos Aires: Amorrortu Editores. (Trabalho original publicado em 1911)

Freud, S. (1988a). El malestar en la cultura. Em J. Strachey (Ed.), Obras completas, Vol. 21 (J. L. Etcheverry, Trad.) (p. 57ss.). Buenos Aires: Amorrortu. (Trabalho original publicado em 1930)

Freud, S. (1988b). El Moisés de Miguel Angel. Em J. Strachey (Ed.), Obras completas, Vol. 1 (J. L. Etcheverry, Trad.) (p. 213ss.). Buenos Aires: Amorrortu. (Trabalho original publicado em 1914)

Freud, S. (1988c). El porvenir de una ilusión. Em J. Strachey (Ed.), Obras completas, Vol. 21 (J. L. Etcheverry, Trad.) (p. 1ss.). Buenos Aires: Amorrortu. (Trabalho original publicado em 1927)

Freud, S. (1988d). El tabú de la virginidad (Contribuciones a la psicología del amor, III). Em J. Strachey (Ed.), Obras completas, Vol. 11 (J. L. Etcheverry, Trad.) (p. 185ss.). Buenos Aires: Amorrortu. (Trabalho original publicado em 1918)

Freud, S. (1988e). Sobre el psicoanálisis de las neurosis de guerra. Em J. Strachey (Ed.), Obras completas, Vol. 17 (J. L. Etcheverry, Trad.) (p. 201 ss.). Buenos Aires: Amorrortu. (Trabalho original publicado em 1919)

Freud, S. (1988f). Sobre la más generalizada degradación de la vida amorosa (Contribuciones a la psicología del amor, II). Em J. Strachey (Ed.), Obras completas, Vol. 11 (J. L. Etcheverry, Trad.) (p. 169ss.). Buenos Aires: Amorrortu. (Trabalho original publicado em 1912)

Freud, S. (1988g). Sobre un tipo particular de elección de objeto en el hombre (Contribuciones a la psicología del amor). Em J. Strachey (Ed.), Obras completas, Vol. 11 (J. L. Etcheverry, Trad.) (p. 155ss.). Buenos Aires: Amorrortu. (Trabalho original publicado em 1910)

Freud, S. (1988h). Tótem y tabú. Em J. Strachey (Ed.), Obras completas, Vol. 13 (J. L. Etcheverry, Trad.) (p. 1ss.). Buenos Aires: Amorrortu. (Trabalho original publicado em 1912)

Freud, S. (1989a). El problema económico del masoquismo. Em J. Strachey (Ed.), Obras completas, Vol. 19 (J. L. Etcheverry, Trad.) (p. 161ss.). Buenos Aires: Amorrortu. (Trabalho original publicado em 1924) 
Freud, S. (1989b). El yo y el ello. Em J. Strachey (Ed.), Obras completas, Vol. 19 (J. L. Etcheverry, Trad.) (p. 1ss.). Buenos Aires: Amorrortu. (Trabalho original publicado em 1923)

Freud, S. (1989c). Fragmento de análisis de un caso de histeria. Em J. Strachey (Ed.), Obras completas, Vol. 7 (J. L. Etcheverry, Trad.) (pp. 1-108). Buenos Aires: Amorrortu. (Trabalho original publicado em 1905)

Freud, S. (1989d). Las resistencias contra el psicoanálisis. Em J. Strachey (Ed.), Obras completas, Vol. 19 (J. L. Etcheverry, Trad.) (p. 223ss.). Buenos Aires: Amorrortu. (Trabalho original publicado em 1925)

Freud, S. (1989e). Más allá del principio de placer. Em J. Strachey (Ed.), Obras completas, Vol. 18 (J. L. Etcheverry, Trad.) (p. 1ss.). Buenos Aires: Amorrortu. (Trabalho original publicado em 1920)

Freud, S. (1989f). Personajes psicopáticos en el escenario. Em J. Strachey (Ed.), Obras completas, Vol. 7 (J. L. Etcheverry, Trad.) (p. 273ss.). Buenos Aires: Amorrortu. (Trabalho original publicado em 1942)

Freud, S. (1989g). Psicología de las masas y análisis del yo. Em J. Strachey (Ed.), Obras completas, Vol. 18 (J. L. Etcheverry, Trad.) (p. 63ss.). Buenos Aires: Amorrortu. (Trabalho original publicado em 1921)

Freud, S. (1989h). Psicopatología de la vida cotidiana. Em J. Strachey (Ed.), Obras completas, Vol. 6 (J. L. Etcheverry, Trad.) (p. 1ss.). Buenos Aires: Amorrortu. (Trabalho original publicado em 1901)

Freud, S. (1989i). Pulsiones y destinos de pulsión. Em J. Strachey (Ed.), Obras completas, Vol. 14 (J. L. Etcheverry, Trad.) (p. 105ss.). Buenos Aires: Amorrortu. (Trabalho original publicado em 1915)

Freud, S. (1989j). Tres ensayos de teoría sexual. Em J. Strachey (Ed.), Obras completas, Vol. 7 (J. L. Etcheverry, Trad.) (p. 109ss.). Buenos Aires: Amorrortu. (Trabalho original publicado em 1905)

Freud, S., \& Breuer, J. (1987). Estudios sobre la histeria. Em J. Strachey (Ed.), Obras completas, Vol. 2 (J. L. Etcheverry, Trad.). Buenos Aires: Amorrortu. (Trabalho original publicado em 1895)

Gabriel, Y. (1988). Freud e a sociedade (V. Ribeiro, Trad.). Rio de Janeiro: Imago. (Trabalho original publicado em 1983)

Goldenberg, R. (1997). Goza!: capitalismo, globalização e psicanálise. Salvador: Ágalma.

Green, A. (1988). Narcisismo de vida, narcisismo de morte (C. Berliner, Trad.) São Paulo: Escuta. (Trabalho original publicado em 1983)

Green, A. (2000). As cadeias de eros - Actualidade do sexual (A. P. Morais, Trad.). Lisboa: CLIMEPSI. (Trabalho original publicado em 1997)

Green, A. (2003a). Quatro questões para André Green/ Quatre questions pour André Green (Versão escrita da "Conversa com André Green" - videoconferência) (A. M. S. Ziskind, M. T. L. Mantovanini \& S. M. C. Marchini, Trads.) (Edição bilingue Português/Francês). São Paulo: Departamento de Publicação da Sociedade Brasileira de Psicanálise de São Paulo.

Green, A. (2003b). Psicanálise contemporânea (Á. Cabral, Org. Trad.). Rio de Janeiro: Imago. (Trabalho original publicado em 2001)

Green, A. (2004). O silêncio do psicanalista (M. S. A. Pereira $\&$ M. A. Mascaux, Trads.). Psyché, VIII, 13-38. (Trabalho original publicado em 1979)
Green, A. (2005). Ideas directrices para un psicoanálisis contemporáneo : desconocimiento y reconocimiento del inconsciente ( $1^{\mathrm{a}}$ ed.) (L. Lambert, Trad.). Buenos Aires: Amorrortu. (Trabalho original publicado em 2003)

Grosskurth, P. (1992). O mundo e a obra de Melanie Klein (P. M. Rosas, Trad.). Rio de Janeiro: Imago. (Trabalho original publicado em 1986)

Grotstein, J. S. (Ed.). (2000). Fairbairn and the origins of object relations. New York: Other Press.

Guimarães, V. C., \& Celes, L.A. M. (2007). O psíquico e o social numa perspectiva metapsicológica: o conceito de identificação em Freud. Psicologia. Teoria e Pesquisa, 23, 241-246.

Heimann, P. (1989). On counter-transference, about children and children-no-longer: Colected papers (1942-80). London: Tavistock: Routledge. (Trabalho original publicado em 1949)

Jorge, M. A. C. (1997). Sexo e discurso em Freud e Lacan. Rio de Janeiro: Jorge Zahar.

Katz, C. S. (1984). Ética e psicanálise: uma introdução. Rio de Janeiro: Grall.

Kehl, M. R. (1996). Psicanálise, ética e política. Em M. I. R. F. França (Ed.), Ética, psicanálise e sua transmissão (pp. 109-121). Petrópolis: Vozes.

Kehl, M. R. (2002). Sobre ética e psicanálise. São Paulo: Companhia das Letras.

Klein, M. (1996). Amor, culpa e reparação e outros trabalhos (1921-1945) (A. Cardoso, Trad.). Rio de Janeiro: Imago. (Trabalho original publicado em 1975)

Kohon, G. (1999). The dead mother: The work of André Green. London: Routledge.

Kristeva, J. (1996). Sens et non-sens de la révolte. Pouvoirs et limites de la psychanalyse I (Discour direct). Paris: Fayard.

Lacan, J. (1978). Escritos (I. Oseki-Depré, Trad.). São Paulo: Perspectiva. (Trabalho original publicado em 1966)

Lacan, J. (1998). Escritos (V. Ribeiro, Trad.). Rio de Janeiro: Jorge Zahar. (Trabalho original publicado em 1966)

Laplanche, J. (1988). Teoria da sedução generalizada e outros ensaios (D. Vasconcellos, Trad.). Porto Alegre: Artes Médicas. (Trabalho original publicado em 1987)

Lorenzer, A. (1973). Bases para una teoría de la socialización. (C. Piechocki, Trad.). Buenos Aires: Amorrortu. (Trabalho original publicado em 1972)

McDougall, J. (1991). Teatros do corpo. O psicossoma em psicanálise (P. H. B. Rondon, Trad.). São Paulo: Martins Fontes. (Trabalho original publicado em 1989)

McDougall, J. (1998). Las mil y una caras de Eros. La sexualidade humana en busca de soluciones (J. Piatigorsky, Trad.). Buenos Aires: Paidós. (Trabalho original publicado em 1995)

Mezan, R. (1990). Freud, o pensador da cultura. São Paulo: Brasiliense.

Ogden, T. H. (2003). Uma nova leitura das origens da teoria das relações de objeto (M. L. Gastal, Trad.). Alter - Jornal de Estudos Psicodinâmicos, XXII, 175-195. (Trabalho original publicado em 2002)

Outeiral, J., Hisada, S., \& Gabríades, R. (2001). Winnicott: seminários paulistas. São Paulo: Casa do Psicólogo.

Outeiral, J., Hisada, S., Gabríades, R., \& Ferreira, A. (2005). Winnicott: seminários brasileiros. Rio de Janeiro: Revinter.

Parsons, M. (2002). Sexualidade e perversão cem anos depois: redescobrindo o que Freud descobriu. International Journal of Psycho-Analysis, XVI, 29-43. 
Pontalis, J. B. (1997). Ce temps qui ne passe pas, suivi de Le compartiment de chemin de fer. Paris: Gallimard.

Pontalis, J. B. (2000). Bisexualité et différence des sexes. Paris: Gallimard.

Rivera, T. C., \& Safatle, V. (2006). Sobre arte e psicanálise. São Paulo: Escuta.

Rouanet, S. P. (1983). Teoria crítica e psicanálise. Rio de Janeiro: Tempo Brasileiro.

Roussillon, R. (2005). La conversation psychanalytique: Un divan en latence. Revue Française de Psychanalyse, 69, 365-381.

Schaeffer, J. (2008). Cent ans après les Trois essais, que reste-t-il des trois scandales? Revue Française de Psychanalyse, 72, 761-776.

Slavutzky, A. (1983). Psicanálise e cultura. Petrópolis: Vozes.

Slavutzky, A., \& Kupermann, D. (2005). Seria trágico... se não fosse cômico: humor e psicanálise. Rio de Janeiro: Civilização Brasileira.

Souza, E. L. A. d. (1999). Psicanálise e colonização: leituras do sintoma social no Brasil. Porto Alegre: Artes e Oficios.

Spillius, E. B. (1990). Melanie Klein hoje: desenvolvimentos da teoria e da técnica - Vol. 2: Artigos predominantemente técnicos (B. H. Mandelbaum, Trad.). Rio de Janeiro: Imago. (Trabalho original publicado em 1988)

Spillius, E. B. (1991). Melanie Klein hoje: desenvolvimentos da teoria e da técnica - Vol. 1: Artigos predominantemente teóricos (B. H. Mandelbaum, Trad.). Rio de Janeiro: Imago. (Trabalho original publicado em 1988)

Strachey, J. (1934). The nature of the therapeutic action of psycho-analysis. International Journal of Psycho-Analysis, 15, 127-159.

Szasz, T. S. (1983). A ética da psicanálise (A. S. da Rocha, Trad.). Rio de Janeiro: Zahar. (Trabalho original publicado em 1965)

Tanis, B. (1995). Memória e temporalidade: sobre o infantil em psicanálise. São Paulo: Casa do Psicólogo.

Vaz, H. C. d. L. (1974). O ethos da atividade científica. REBRevista Eclesiástica Brasileira, 133, 45-73.
Viana, T. d. C. (2007). Estudos de costumes no século XIX, de Félix Davin e Honoré de Balzac. Brasília: Universidade de Brasília.

Winnicott, D. W. (1975). O brincar \& a realidade (J. O. A. Abreu \& V. Nobre, Trads.). Rio de Janeiro: Imago Editora (Trabalho original publicado em 1971)

Winnicott, D. W. (1978). Textos selecionados: da pediatria à psicanálise (J. Russo Trad.). Rio de Janeiro: Francisco Alves (Trabalho original publicado em 1975)

Winnicott, D. W. (1983). O ambiente e os processos de maturação: estudos sobre a teoria do desenvolvimento emocional (I. C. S. Ortiz Trad.). Porto Alegre: Artes Médicas. (Trabalho original publicado em 1979)

Winnicott, D. W. (1990). Natureza humana (D. L. Bogomoletz, Trad.). Rio de Janeiro: Imago. (Trabalho original publicado em 1988)

Winnicott, D. W. (1994). A importância do setting no encontro com a regressão na psicanálise. Em C. Winnicott, R. Shepherd \& M. Davis (Eds.), Explorações psicanalíticas. D. W. Winnicott (J. O.A. Abreu, Trad.) (pp. 77-81). Porto Alegre: Artes Médicas. (Trabalho original publicado em 1964)

Winnicott, D. W. (1996). Tudo começa em casa (P. Sandler, Trad.) São Paulo: Martins Fontes. (Trabalho original publicado em 1986)

Winnicott, D. W. (2005). Privação e delinquência (2 $2^{\mathrm{a}}$ ed) (Á. Cabral, Trad.). São Paulo: Martins Fontes. (Trabalho original publicado em 1984)

Winnicott, C., Shepherd, R., \& David, M. (1994). Explorações psicanaliticas: D. W. Winnicot. (J. O. A. Abreu, Trad.). Porto Alegre: Artes Médicas Sul. (Trabalho original publicado em 1989)

Zavaroni, D. M. L., \& Celes, L. A. M. (2004). O processo civilizador: uma leitura da pulsão de morte como excessivo pulsional na compreensão freudiana da cultura. Pulsional: Revista de Psicanálise, 17, 66-77.

Zavaroni, D. M. L., Viana, T. D.. C., \& Celes, L. A. M. (2007). A constituição do infantil na obra de Freud. Estudos de Psicologia (Natal), 12, 65-70. 